\title{
The Disappearance of Coal Seams Recorded in Associated Gangue Rocks in the SW Part of the Upper Silesian Coal Basin, Poland
}

\author{
Justyna Ciesielczuk *(), Monika J. Fabiańska ${ }^{\mathbb{D}}$, Magdalena Misz-Kennan, Dominik Jura, Paweł Filipiak \\ and Aniela Matuszewska
}

check for updates

Citation: Ciesielczuk, J.; Fabiańska, M.J.; Misz-Kennan, M.; Jura, D.; Filipiak, P.; Matuszewska, A. The Disappearance of Coal Seams Recorded in Associated Gangue Rocks in the SW Part of the Upper Silesian Coal Basin, Poland. Minerals 2021, 11, 735. https://doi.org/ $10.3390 / \min 11070735$

Academic Editor: Shifeng Dai

Received: 20 May 2021

Accepted: 3 July 2021

Published: 7 July 2021

Publisher's Note: MDPI stays neutral with regard to jurisdictional claims in published maps and institutional affiliations.

Copyright: (c) 2021 by the authors. Licensee MDPI, Basel, Switzerland. This article is an open access article distributed under the terms and conditions of the Creative Commons Attribution (CC BY) license (https:// creativecommons.org/licenses/by/ $4.0 /)$.
Institute of Earth Sciences, University of Silesia, 60 Będzińska Str., PL-41-200 Sosnowiec, Poland; monika.fabianska@us.edu.pl (M.J.F.); magdalena.misz@us.edu.pl (M.M.-K.); dominik.jura@us.edu.pl (D.J.); pawel.filipiak@us.edu.pl (P.F.); aniela.matuszewska@us.edu.pl (A.M.)

* Correspondence: justyna.ciesielczuk@us.edu.pl; Tel.: +48-323689336

\begin{abstract}
Coal seams in the Upper Silesian Coal Basin vanish within the Carboniferous Upper Silesian Sandstone Series and below an unconformity marking the Carboniferous top surface. Changes in the geochemical, mineralogical, petrological and palynological characteristics of gangue rocks associated with the vanished seams record what happened. The observed changes could have been caused by (1) coal-seam paleofire, (2) peat combustion, (3) igneous intrusion, (4) metasomatism and/or (5) weathering. Multifaceted research on samples collected at the Jas-Mos mining area, a part of the operating Jastrzebie-Bzie Coal Mine that are representative of different geological settings in the northern and southern parts of the mining area, point to intra-deposit paleofire as the most plausible reason for the disappearance. Biomarkers enabled recognition of differences in heating duration and oxygen access. Coal seams in the south burned quickly with abundant oxygen supply. Seams in the north pyrolyzed for an extended time under conditions of limited oxygen. Though other methods used proved less sensitive, all confirmed low $\left(100-150^{\circ} \mathrm{C}\right)$ paleotemperature heating. Overall, the reason for the local disappearance of the coal seams, making their exploitation difficult and unprofitable, can be assigned to a variety of different processes in a complex overlapping history of variable weathering, heating due to local endogenic fires and, probably, earlier peat combustion.
\end{abstract}

Keywords: disappearing coal seam; thermal alteration of gangue rocks; paleofire; Upper Silesian Coal Basin

\section{Introduction}

Coal and coal-bearing rocks in the south-western part of the Upper Silesian Coal Basin (USCB) of Early Pennsylvanian (Namurian BC) age underwent changes resulting in the partial/complete disappearance of coal seams over an area of ca $500 \mathrm{~km}^{2}$. This disappearance is associated with gangue rocks of various colors, typically located above the seams. Maximum noticed thickness reduction up to disappearing was observed in coal seam No. 505, which, with a regular thickness of ca $5 \mathrm{~m}$, shows this most clearly-though the problem concerns coal seams Nos. 415/1 and 510 [1], 504, 505 and 506 [2-4] and 406/4 [5], exploited in both the Polish and Czech parts of the USCB. The coal there, if any, is grey-black, dull, heavily cracked, brittle and without a banded structure. The altered, variably colored coal-bearing rocks are characterized by increased fracturing, porosity and reduction of physical and mechanical properties [6,7], all a reflection of oxidation and heating.

Changes in the gangue rocks accompanying the vanishing coal seams may have been caused by weathering and thermal alteration of coal-bearing sediments locally preserved below a regional unconformity marking the Carboniferous top surface and within intraPennsylvanian disconformities [8]. General (geological) and detailed (petrographical, 
geochemical, palynological) descriptions of these variably colored beds indicate weathering effects and/or thermal transformations, the origin of which is not clear, as subsurface mapping and sample collection is possible only from boreholes and single outcrops in operating coal mines. As exploitation avoids regions possibly lacking coal, these parts of mines are abandoned and inaccessible.

Several underground outcrops with vanishing coal seams and weathered and/or thermally altered gangue rocks of various types and irregular geometries occur in the mining areas between Jastrzębie in Poland and Karviná in the Czech Republic (Figure 1). Anomalies favoring reduced coal-seam thickness and increasing coalification occur mainly in the coalfield of the Jas-Mos, a part of the Jastrzębie-Bzie Coal Mine (Figures 2 and 3).

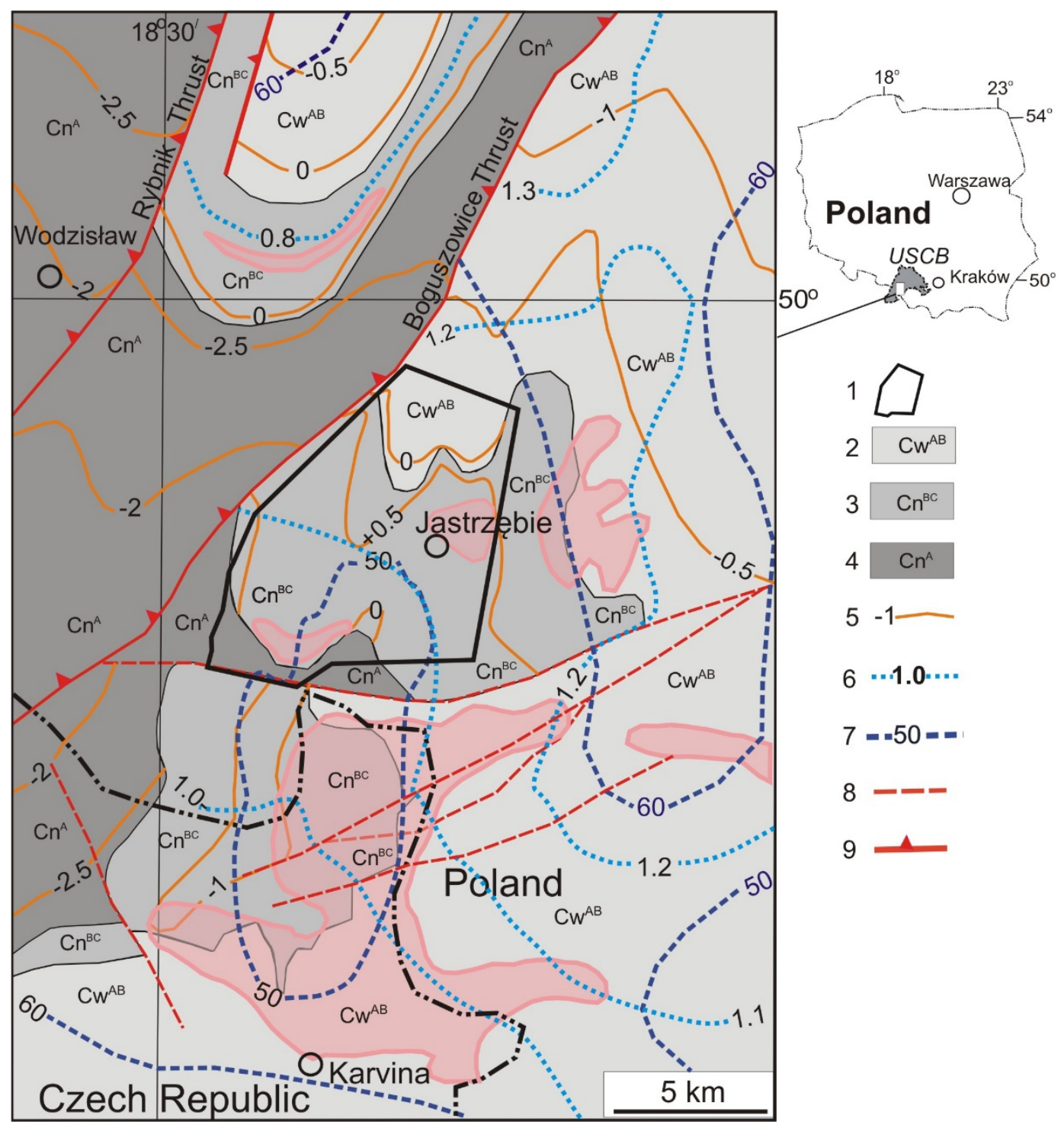

Figure 1. Subsurface structural map of the Carboniferous coal-bearing Paralic, Upper Silesian Sandstone and Mudstone Series in the western part of the Upper Silesian Coal Basin (USCB) (after [9,10]; simplified). Areas with vanishing coal seams and associated altered gangue rocks at the top of the Carboniferous units are shown in pink. 1: Jas-Mos mining area, a part of the Jastrzebie-Bzie Coal Mine; 2: Mudstone Series, Westphalian $\mathrm{AB}\left(\mathrm{Cw}^{\mathrm{AB}}\right)$, with bottom isolines (coal seam 405); 3: Upper Silesian Sandstone Series, Namurian BC $\left(\mathrm{Cn}^{\mathrm{BC}}\right)$, with bottom isolines (coal seam 510); 4: Paralic Series, Namurian $\mathrm{A}\left(\mathrm{Cn}^{\mathrm{A}}\right)$, with bottom isolines; 5: bottom isolines in $\mathrm{km}$ a.s.1.; 6 : isolines of average random vitrinite reflectance $\mathrm{R}_{\mathrm{r}}(\%)$; 7: isolines of average vitrinite content (\%); 8: fault; 9: thrust. 


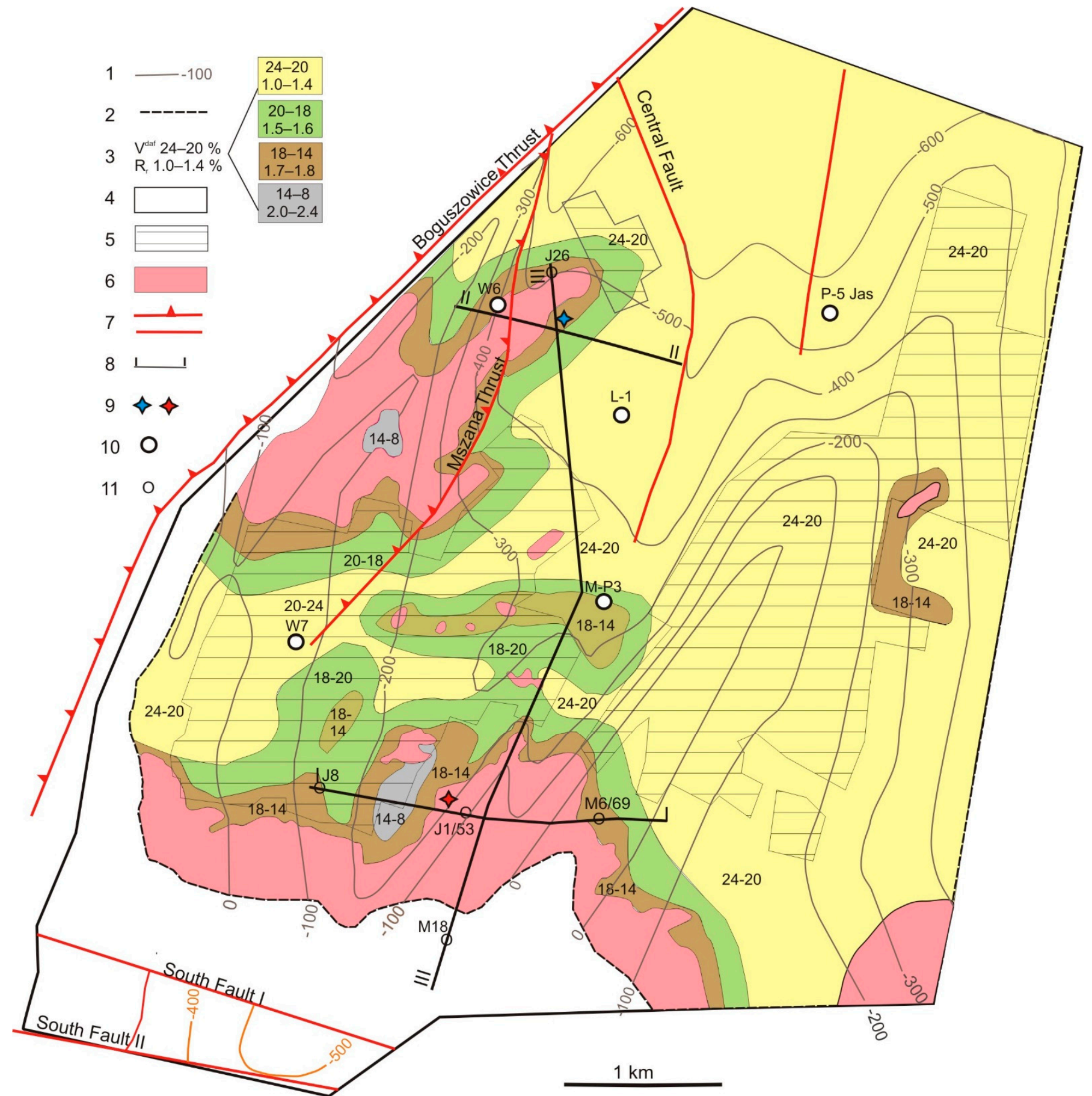

Figure 2. Structural sketch map of the coal seam No. 505 in the Jas-Mos mining area, a part of the Jastrzębie-Bzie Coal Mine, and its disappearance (based on geological documentation of Jastrzębie-Bzie Coal Mine, simplified). 1: isoline of the bottom of coal seam No 505 in m a.s.l.; 2: subcrop of 505 coal seam below Miocene claystone; 3: coal rank and quality-isolines of the average volatile matter content ( $\mathrm{V}^{\text {daf }} \%$ ), vitrinite reflectance $\mathrm{R}_{\mathrm{r}} \%$ and coal types; 4: unexploited coalfield, 5: exploited coal; 6: altered associated gangue rocks and vanishing coal seam 505; 7: fault and thrust; 8: geological cross-section lines; 9: outcrops of coal seam 505 in testing gallery 47 (samples N1-N8 in blue) and in south corridor II below coal seam 418 (samples S1-S6 in red); 10: shaft; 11: drilling. 
(a)

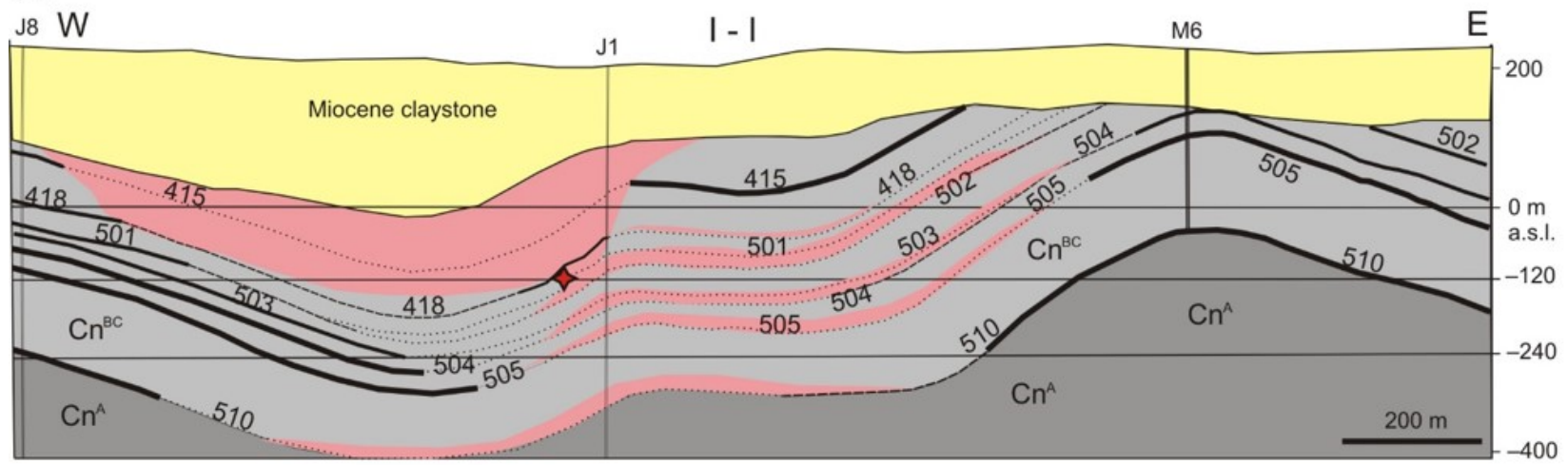

(b)

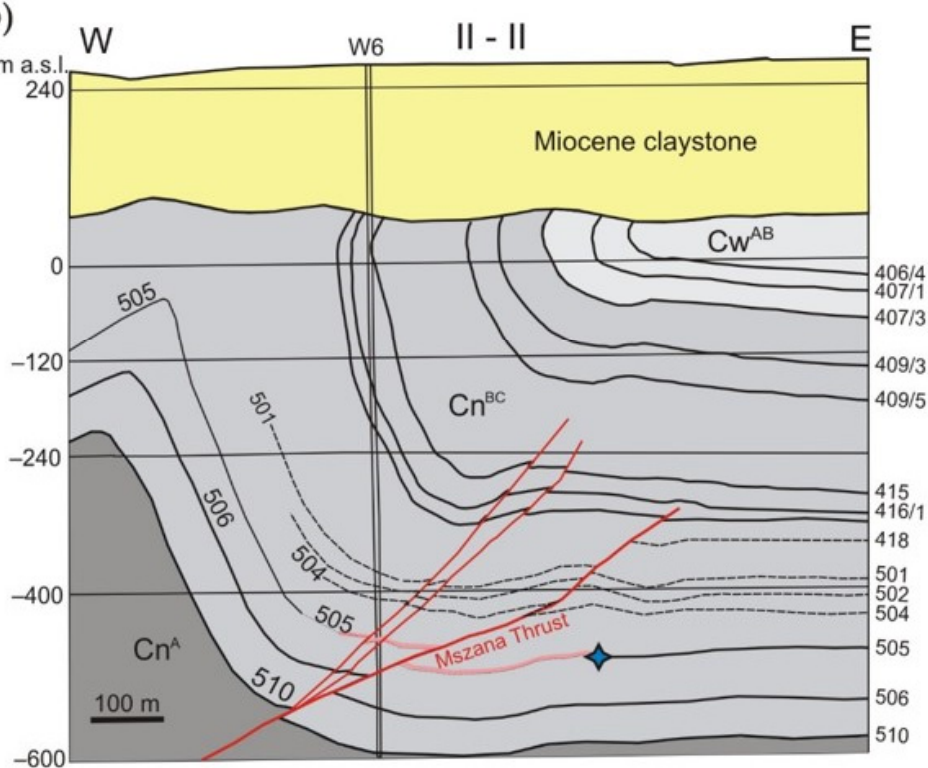

_ $\quad$ partly mined, regular coal seams

- - thinned coal seams

vanishing coal seams with associated altered gangue rocks

location of samples N1-N8

location of samples S1-S6

(c)

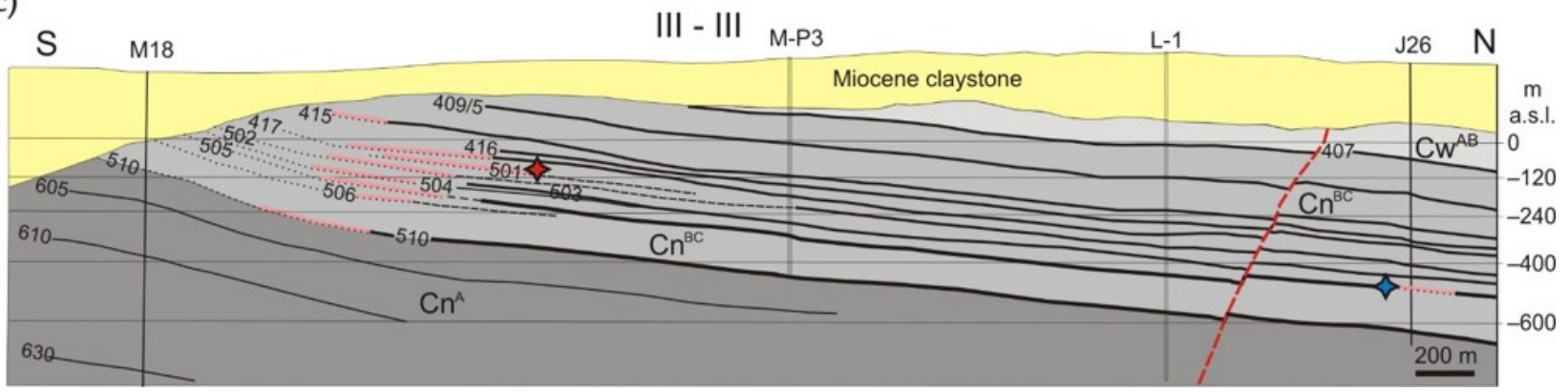

Figure 3. Cross-sections showing simplified geological settings in different areas of the Jas-Mos mining area, a part of the operating Jastrzębie-Bzie Coal Mine, with sample collecting locations (based on geological documentation of Jastrzębie-Bzie Coal Mine, simplified). (a) W-E southern cross-section I-I and location of samples S1-S6 in south corridor II below coal seam 418; (b) W-E northern cross-section II-II with location of samples N1-N8 collected from the outcrop of 505 seam in testing gallery 47 , where the seam thins from $3.2 \mathrm{~m}$ to $0.4 \mathrm{~m}$, at the distance of $30 \mathrm{~m}$; (c) parallel N-S cross-section III-III, showing the position of samples N1-N8 and S1-S6.

\subsection{Geological Background}

On the western margin of the USCB, the Mudstone-Sandstone Paralic Series of the Latest Mississippian age (Namurian A) are discordantly overlapped by the Upper Silesian Sandstone Series of Early Pennsylvanian age (Namurian BC). The coal seam No.510 is 
considered the bottom of the latter, which represents ca $500 \mathrm{~m}$ thick limnic upper-delta-plain succession of a braided river system, hosting ca 22 coal seams (Figures 1 and 3). Its lower part contains thick $(<24 \mathrm{~m})$ but splitting coal seams (Nos. 501-510, the upper part hosts thin $(<2.5 \mathrm{~m}$ ) coal seams (Nos. 407-418). They constitute $6-8 \%$ of the unit $[11,12]$. Within these beds, locally developed intra-formational disconformities are accompanied by weathered and thermally altered coal-bearing rocks with disappearing coal seams. The Upper Silesian Sandstone Series is followed by the Mudstone Series of the Middle Pennsylvanian age (Westphalian $\mathrm{AB}$ ). Its bottom sets out freshwater fauna level and contains ca 70 coal seams of thickness in the range of 0.9-2.5 $\mathrm{m}$.

The western part of the USCB is deformed by folds, faults and thrusts. In the Jas-Mos mining area of the Jastrzebie-Bzie Coal Mine, the broad syncline and narrow anticline of the Jastrzebie Fold and the Mszana Thrust spread longitudinally in the front of the Boguszowice Thrust (Figures 1-3). Uplift and tectonic inversion of the USCB reflects coeval Late Pennsylvanian folding. The Late Variscan Upper Silesian fold-and-thrust mountain belt was deeply eroded to a depth of several kilometers during Stephanian and Permian times [13]. Any understanding of the evolution of the Variscan topographic surface must encompass the uplifting of the lithified Carboniferous rocks hosting bituminous coal (Figure 1).

Coalification increases with stratigraphic depth in the western and central parts of the basin. Vitrinite reflectance ranges from $0.6 \%$ to $1.5 \%$, with an average $R_{r}$ gradient of $0.2 \% / \mathrm{km}$, suggesting maturation due to USCB subsidence. The salinity of waters in the coal-bearing series also increases, with burial from $35 \mathrm{~g} / \mathrm{dm}^{3}$ to $200 \mathrm{~g} / \mathrm{dm}^{3}$, at average gradients of $\sim 150 \mathrm{~g} / \mathrm{dm}^{3} / \mathrm{km}$. The coals absorbed considerable amounts of methane; contents increase from 1 to $18 \mathrm{~m}^{3} / \mathrm{Mg}$ (dry ash free) between 500 and $1800 \mathrm{~m}$ below the Carboniferous top surface [12,14,15]. Coal-bed methane contents in the Jastrzebie-Bzie Coal Mine area are low $\left(<2 \mathrm{~m}^{3} / \mathrm{Mg}\right.$ of coal). During subsidence and burial to a depth below $\sim 1.5 \mathrm{~km}$, thermogenic methane was generated at temperatures $>50{ }^{\circ} \mathrm{C}$ in coal seams, with $\mathrm{R}_{\mathrm{r}}$ of $\sim 0.7 \%$ [16]. This calculation is based on hydrostatic pressure gradients $(10 \mathrm{MPa} / \mathrm{km})$ and temperature gradients $\left(30^{\circ} \mathrm{C} / \mathrm{km}\right)$ in the USCB during the Pennsylvanian.

Several explanations view coalification as a function of burial depth and duration, geothermal impact of hot fluid flow from the basement or heating by tectonic contractions and intrusions [17]. Coal-rank maps of the USCB show an increase in vitrinite reflectance and carbon content (or decrease of volatile matter) due to increasing burial (Figure 1) rather than intense seam folding [18]. Folding of the USCB was initiated by uplift and erosion, mainly at the western part of the basin margins, exposing high-rank coals in the cores of anticlines and synclines.

The coals in the Upper Silesian Sandstone Series are characterized by variable average vitrinite contents ranging from $<50 \%$ to $>60 \%$ (Figure 1 ). Locally, coal seams Nos. $406 / 4$, $415 / 1,418,501,504,505,506$ and 510 show anomalous degrees of oxidized alteration and thermal metamorphism [1-5]. In the Jas-Mos mining area, a part of the Jastrzebie-Bzie Coal Mine, coal rank varies from high volatile bituminous $C$ to semi-anthracite; vitrinite reflectance $\left(\mathrm{R}_{\mathrm{r}}\right)$ increases from $1.0 \%$ to $2.4 \%$ and volatile matter $\left(\mathrm{V}^{\text {daf }}\right)$ decreases from $24 \%$ to $8 \%$ (Figure 2). Average values of $\mathrm{V}^{\text {daf }}$ in seams Nos. 418 and 505 range from $26 \%$ to $8 \%$. This parameter is compatible with vitrinite reflectance $\left(R_{r}\right)$, ranging from $1.0 \%$ to $2.4 \%$ in heated coal (Figure 2). These coal seams show variable contents of vitrinite and inertinite and of liptinite $(<5 \%)$. Weaker coking properties in disappearing parts of the coal seams are linked with increasing contents of inertinite [2].

\subsection{Weathering and Thermally Altered Coal-Bearing Deposits}

Coal-bearing siliciclastic sediments on outcrops are susceptible to weathering and have a propensity to self-heat and self-ignite [19]. In coalfields, these processes also occur in opencast and underground mines, especially in coal stockpiles and coal-bearing waste dumps [20-23]. Weathered limnic Upper Silesian Sandstone Series rocks occur below the sub-Miocene unconformity of the regional Carboniferous top surface [8]. The degree of 
weathering is indicated by a change in color, an increase in friability and volatile matter contents. Oxidized coals and sediments forming a varicolored alteration horizon about 10$30 \mathrm{~m}$ thick are common in sub-crops below the overburden of Permian volcanoclastics and, locally, below Triassic and Miocene siliciclastics [1,14,24] (Figures 1 and 3). The chemically and physically altered varicolored sediments and weathered layers retain the structures and fabric of the parent rocks.

Thermal alteration is evident in gangue rocks overlying burnt-out coal seams as collapsed breccias with red, pink and severely fractured claystones and porcelanites similar to clinker, or as highly sintered residuum containing high-temperature minerals, such as mullite and cristobalite. The fire is deemed to have been Cretaceous-Paleogene in age $[3,6,7,24-26]$ and personal communication from mine geologists. An example is the burnt coking 504 and 505 Coal Seam below the Carboniferous top surface in the Jas-Mos mining area, a part of the Jastrzebie-Bzie Coal Mine, which thins over a distance of $4 \mathrm{~m}$ and changes into low volatile bituminous coal with the characteristic metallic luster of anthracites [2,4].

Coal seams can also vanish due to peat combustion in the Early Pennsylvanian, causing intra-Pennsylvanian disconformities. Peats accumulating on the alluvial plain could be disrupted by uplift resulting in erosion, oxidation and spontaneous combustion.

Changes seen in coals and coal-bearing sedimentary rocks can also be caused by thermal metamorphism [4,27-30]. Coal seam No. 504 in the USCB was considered to be thermally metamorphosed due to non-dated igneous activity [2]. However, recent carbon-isotope investigations on coal from different coal seams in the USCB, on naturally heated coal and on coal heated in the laboratory, exclude this possibility [31].

The aim of our research was (1) to determine whether the variety of alterations seen were caused by coal-seam fire, peat fire or magmatic intrusion, (2) to investigate changes in the maceral composition, geochemistry, mineralogy and palynology of rocks associated with disappearing coal seams and (3) to elucidate any differences in coal-seam fire conditions between the northern and southern parts of the Jas-Mos minefield of the Jastrzębie-Bzie Coal Mine.

\section{Materials and Methods}

\subsection{Sample Description and Preparation}

Gangue rocks accompanying disappearing coal seams in different positions in the Upper Silesian Sandstone Series were collected in two sets representing the northern and southern areas of the Jas-Mos mining area of the Jastrzebie-Bzie Coal Mine, respectively. Twelve reddish samples of siltstone and carbonate were collected in the second south corridor located at $-120 \mathrm{~m}$ a.s.l., between the disappearing semi-anthracite seam No. 418 and coking seam No. 501 (Figures 2 and 3a,c). In 2012, geologists from the JasMos Coal Mine (Jastrzębie-Bzie at present) collected 28 samples of gangue rocks located above disappearing coal seam No. 505 in testing gallery 47 located at $-500 \mathrm{~m}$ a.s.l. in the Jastrzębie syncline axis (Figures 2 and $3 b, c)$. These are siltstones locally containing carbonate, hematite and plant fossils. Samples from the northern and southern parts of the Jas-Mos mining area differ macroscopically in color; those from the northern part are dark grey with coal laminae and red streaks or patches (Figure $4 a, b$ ), whereas those from the southern part are orange-red and contain much less organic matter as smaller particles between mineral grains (Figure 4c,d). Eight representative dark-grey samples (N1-N8) and six red-orange samples (S1-S6) were selected for detailed investigations. 

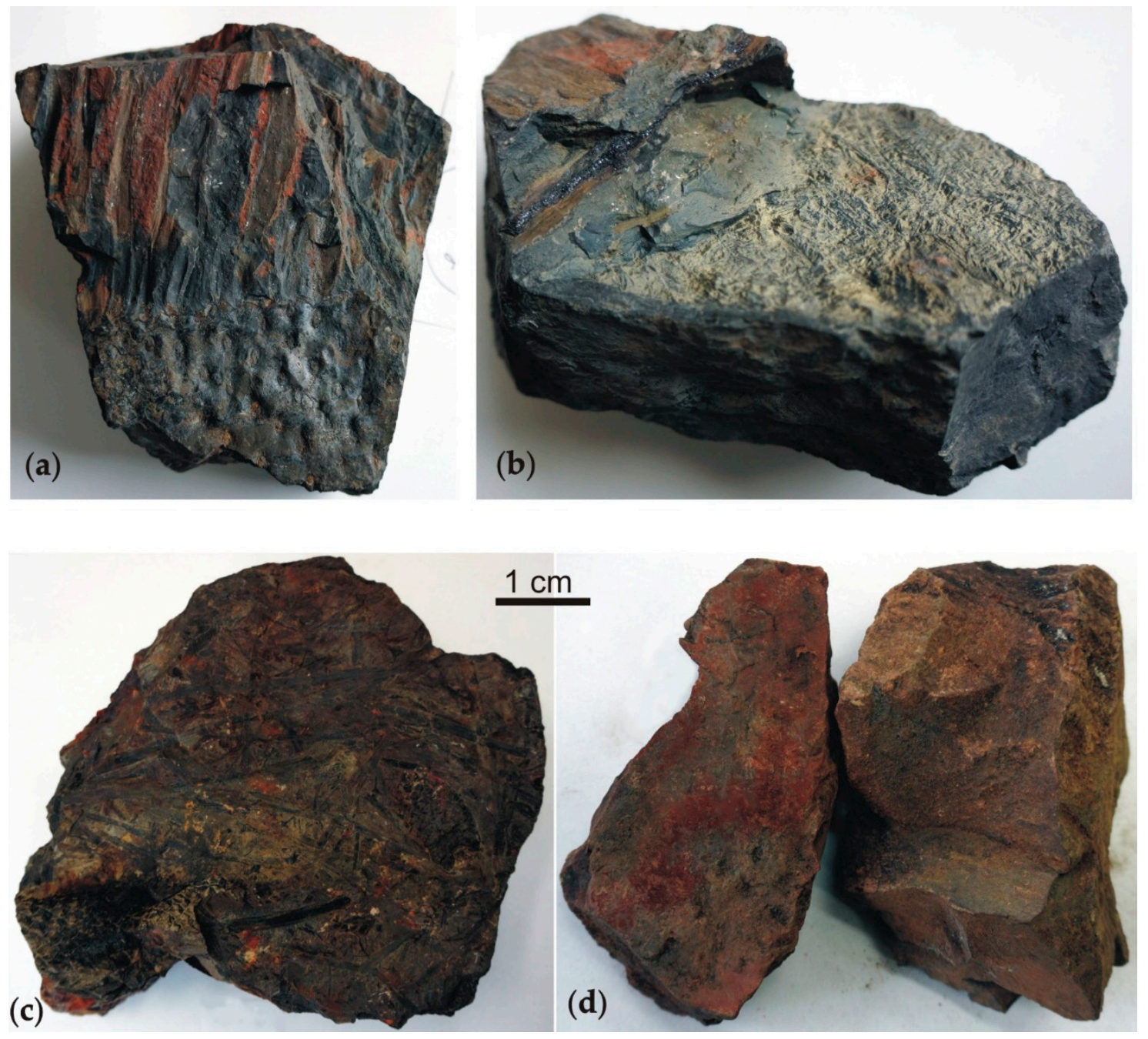

Figure 4. Samples collected from the vicinity of the disappearing coal seams located in the northern part, (a) sample N1 and (b) sample N4, and southern part, (c) sample S2 and (d) sample S5, of the Jas-Mos mining area, a part of the Jastrzębie-Bzie Coal Mine.

\subsection{Organic Petrography}

Samples crushed to $<1 \mathrm{~mm}$ were embedded in epoxy resin and polished blocks were prepared for microscopic examination according to the procedures described in [32]. Vitrinite, liptinite, inertinite and mineral contents were determined at 500 points in each sample. Analyses were carried out in reflected white light according to the procedure described in [33], applying ICCP terminology [34-36]. Random reflectance $\left(R_{r}\right)$ measurements were carried out according to [37] at 50 points in each sample containing organic matter.

\subsection{Mineralogy and Chemistry}

Rock samples for chemical analyses were split, crushed, then weathered parts and macroscopically seen vein fillings were removed and $250 \mathrm{~g}$ were dried and pulverized to $\geq 85 \%$ passing $75 \mu \mathrm{m}$. Whole-rock 20 major oxides and 45 trace-element contents were determined by ICP-ES and ICP-MS at ACME Laboratories, Canada.

At the Faculty of Natural Sciences, University of Silesia, Sosnowiec, Poland, phase compositions of powdered samples were determined using a fully automated X-ray Philips PW 3710 diffractometer operated at $45 \mathrm{kV}$ and $30 \mathrm{~mA}, \mathrm{CuK} \alpha$ radiation and equipped with a graphite monochromator. Mineral morphologies and spatial relationships between components were examined in thin sections and samples fragments using a Philips XL 30 ESEM/TMP scanning electron microscope in environmental mode, coupled with an 
energy-dispersive spectrometer (EDS; EDAX type Sapphire). Analytical conditions of the SEM were: accelerating voltage of $15 \mathrm{kV}$; a working distance of ca $10 \mathrm{~mm}$; counting time of $40 \mathrm{~s}$. The Raman spectra were recorded on a WITec alpha 300R Confocal Raman Microscope equipped with an air-cooled solid laser $532 \mathrm{~nm}$ and a CCD camera operating at $-61^{\circ} \mathrm{C}$. The laser radiation was coupled to a microscope through a single-mode optical fiber with a diameter of $3.5 \mu \mathrm{m}$. An air Zeiss LD EC Epiplan-Neofluan DIC-100/0.75NA objective was used.

\subsection{Palynology}

Seven samples (N1-N5, N7 and N8) from the northern area and four (S2-S5) from the southern area were chemically processed using standard palynological $(\mathrm{HCl}-\mathrm{HF}-\mathrm{HCl})$ procedures [38]. All samples from the northern locality were positive, but only two (S2 and S4) from the southern area yielded organic content. Productive samples were grey and negative samples red in color. All positive samples from both areas possessed poorly preserved palynomorphs, mainly spores, pollen grains, plant tracheids and cuticles. Traces of amorphic organic matter (AOM) were noted in samples from the southern area. In both areas, spore exines were slightly to strongly corroded and thermally altered.

At least two slides were prepared from each residue. Cellosize was used as a dispersal agent to avoid organic clumping and Peropoxy 154 was used as a mounting agent. A transmitted light microscope (Nikon Eclipse 50i with integrated DS-Fi2 digital camera) was used. The palynological slides and residues are housed at the Faculty of Natural Sciences at the University of Silesia.

\subsection{Organic Geochemistry}

\section{Solvent Extraction}

After powdering samples to $<0.2 \mathrm{~mm}, 8-12 \mathrm{~g}$ aliquots of each were taken for extraction with dichloromethane (DCM). The Dionex 350 Accelerated Solvent Extractor system (Thermo Scientific) at $70{ }^{\circ} \mathrm{C}$ in $34 \mathrm{~mL}$ stainless steel cells ( $\mathrm{p}=10 \mathrm{Mpa}$; solvent flow = $70 \mathrm{~mL} / \mathrm{min}$ ) was applied. The solvent was evaporated at room temperature and dried extracts weighed to calculate extraction yields (wt.\%; Table 1). The dry residue was diluted in $0.5 \mathrm{~mL}$ of DCM and analyzed with GC-MS. All solvents and reagents applied were pure for analysis grade (Avantor Performance Materials Poland S.A.). The analysis of each sample series was accompanied by the analysis of a blank sample of the extracting silica gel (Merck, Kieselgel 60, 63-200 $\mu \mathrm{m}$ ) under the same conditions as for the samples.

\section{Gas Chromatography-Mass Spectrometry (GC-MS)}

Prior to GC-MS, extracts for analysis were not separated into compound groups due to their low extractability. An Agilent gas chromatograph 6890 with a DB-35 column $(60 \mathrm{~m} \times 0.25 \mathrm{~mm}$ i.d.), coated by a $0.25 \mu \mathrm{m}$ stationary phase film coupled with an Agilent Technology mass spectrometer 5973 was used. The experimental conditions were as follows: carrier gas, He; temperature, $50{ }^{\circ} \mathrm{C}$ (isothermal for $2 \mathrm{~min}$ ); heating rate, up to $175{ }^{\circ} \mathrm{C}$ at $10{ }^{\circ} \mathrm{C} \mathrm{min}-1,225^{\circ} \mathrm{C}$ at $6^{\circ} \mathrm{C} \mathrm{min}^{-1}$ and, finally, $300{ }^{\circ} \mathrm{C}$ at $4{ }^{\circ} \mathrm{C} \mathrm{min}^{-1}$. The final temperature $\left(300^{\circ} \mathrm{C}\right.$ ) was held for $20 \mathrm{~min}$. The mass spectrometer was operated in the electron impact ionization mode at $70 \mathrm{eV}$ and scanned from 50-650 da. Data were acquired in a full scan mode and processed with the Hewlett Packard Chemstation software. The compounds were identified by using their mass spectra, comparison of peak retention times with those of standard compounds, interpretation of MS fragmentation patterns and literature data $[39,40]$. Geochemical parameters were calculated using peak areas acquired in the manual integration mode. 
Table 1. Petrographic properties and extraction yields of the gangue-rocks samples from the northern (N1-N8) and southern (S1-S6) parts of the Jas-Mos mining area, a part of the Jastrzebie-Bzie Coal Mine.

\begin{tabular}{ccccccccc}
\hline $\begin{array}{c}\text { Sample } \\
\text { No. }\end{array}$ & $\begin{array}{c}\text { Vitrinite } \\
\mathbf{( \% )}\end{array}$ & $\begin{array}{c}\text { Liptinite } \\
\mathbf{( \% )}\end{array}$ & $\begin{array}{c}\text { Inertinite } \\
\mathbf{( \% )}\end{array}$ & $\begin{array}{c}\text { Minerals } \\
\mathbf{( \% )}\end{array}$ & $\begin{array}{c}\mathbf{R}_{\mathbf{r}} \\
\mathbf{( \% )}\end{array}$ & SD & $\begin{array}{c}\text { Extraction Yield } \\
\mathbf{( w t .} \% \mathbf{)}\end{array}$ \\
\hline N1 & 2.4 & 0.0 & 0.6 & 97.0 & 1.16 & 0.06 & 50 & 0.0520 \\
N2 & 1.4 & 0.0 & 0.0 & 98.6 & 1.37 & 0.21 & 50 & 0.0511 \\
N3 & 0.8 & 0.0 & 0.2 & 99.0 & 1.42 & 0.27 & 50 & 0.0400 \\
N4 & 2.2 & 0.0 & 0.0 & 97.8 & 1.17 & 0.18 & 50 & 0.0379 \\
N5 & 1.2 & 0.0 & 1.0 & 97.8 & 1.10 & 0.16 & 50 & 0.0580 \\
N6 & 28.0 & 0.0 & 0.0 & 72.0 & 1.33 & 0.05 & 50 & 0.0352 \\
N7 & 1.8 & 0.0 & 0.0 & 98.2 & 1.25 & 0.21 & 50 & 0.0222 \\
N8 & 0.6 & 0.0 & 0.0 & 99.4 & 1.50 & 0.31 & 50 & 0.0104 \\
S1 & 0.0 & 0.0 & 0.0 & 100.0 & - & - & - & 0.0008 \\
S2 & 1.6 & 0.0 & 0.0 & 98.4 & 1.08 & 0.19 & 25 & - \\
S3 & 0.0 & 0.0 & 0.0 & 100.0 & - & - & 0.0153 \\
S4 & 0.6 & 0.0 & 0.0 & 99.4 & 1.27 & 0.25 & 25 & 0.0190 \\
S5 & 0.0 & 0.0 & 0.0 & 100.0 & - & - & - & 0.0090 \\
S6 & 0.0 & 0.0 & 0.0 & 100.0 & - & - & - & 0.0035 \\
\hline Average N & 4.8 & 0.0 & 0.2 & 95.0 & 1.29 & 0.18 & 50 & 0.0196 \\
\hline Average S & 0.4 & 0.0 & 0.0 & 99.6 & $1.18 *$ & $0.22 *$ & 25 & 0.0383 \\
\hline
\end{tabular}

n: number of reflectance measurements; ${ }^{*}$, the value calculated on the base of two samples.

\section{Results and Discussion}

\subsection{Organic Petrography}

Samples from the northern (N1-N8) and southern (S1-S6) parts of the Jas-Mos mining area differ in amounts of organic matter, being $5.0 \%$ on average in the former and $0.4 \%$ in the latter (Table 1). Typically, contents of organic matter in the northern part are $<3.0 \%$, but sample N6, with $28.0 \%$, is the exception that serves to exaggerate the averaged difference. Most samples from the southern part contain no organic matter.

Macroscopically, organic matter is dispersed in samples of rocks co-occurring with the 418 and 505 coal seams. Single thin coal laminae are present in sample N6 (Figure 5). Microscopically, this sample is dominated by macerals of the vitrinite group as is typical for USCB coals $[9,10,41]$. They are usually represented by vitrodetrinite that is small and irregular, or by collotelinite present as laminae, ranging up to a few tens of micrometers and which are commonly cracked (Figures 5 and 6). The cracks are often filled with minerals. Corpogelinite is a rare presence. The average content of vitrinite macerals in samples from the northern part is $4.8 \%(1.5 \%$, excluding N6) and $0.4 \%$ in those from the southern part. Inertinite macerals, represented by fusinite, semifusinite and inertodetrinite, are present $(0.2-1.0 \%$, average $0.2 \%)$ in N1, N3 and N5 only. These macerals are present in samples $\mathrm{N} 2, \mathrm{~N} 4, \mathrm{~N} 7, \mathrm{~N} 8, \mathrm{~S} 2$ and S4, but their contents are below the detection limit $(<0.2 \%)$. In the remaining samples, inertinite does not occur. Liptinite was absent in all samples.

Random reflectance $\left(\mathrm{R}_{\mathrm{r}}\right)$ values lie between $1.08 \%$ (S2) and 1.50\% (N8). Except for N1 and N6 (Figure 7), the dispersion of values is wide, indicating alteration of organic matter that might be caused by heating, as indicated by the presence of graphitized carbon in sample S4. 

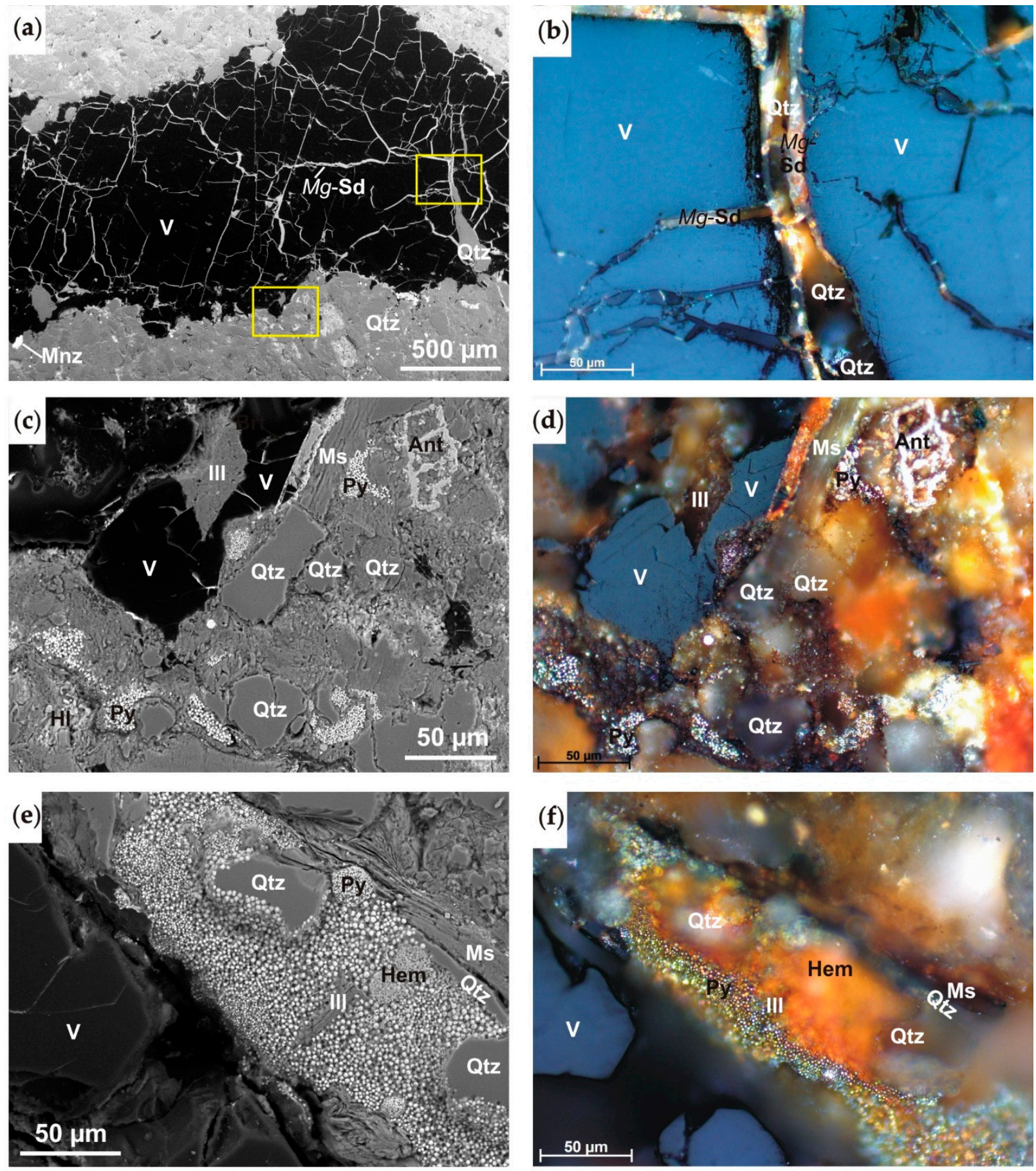

Figure 5. Cont. 

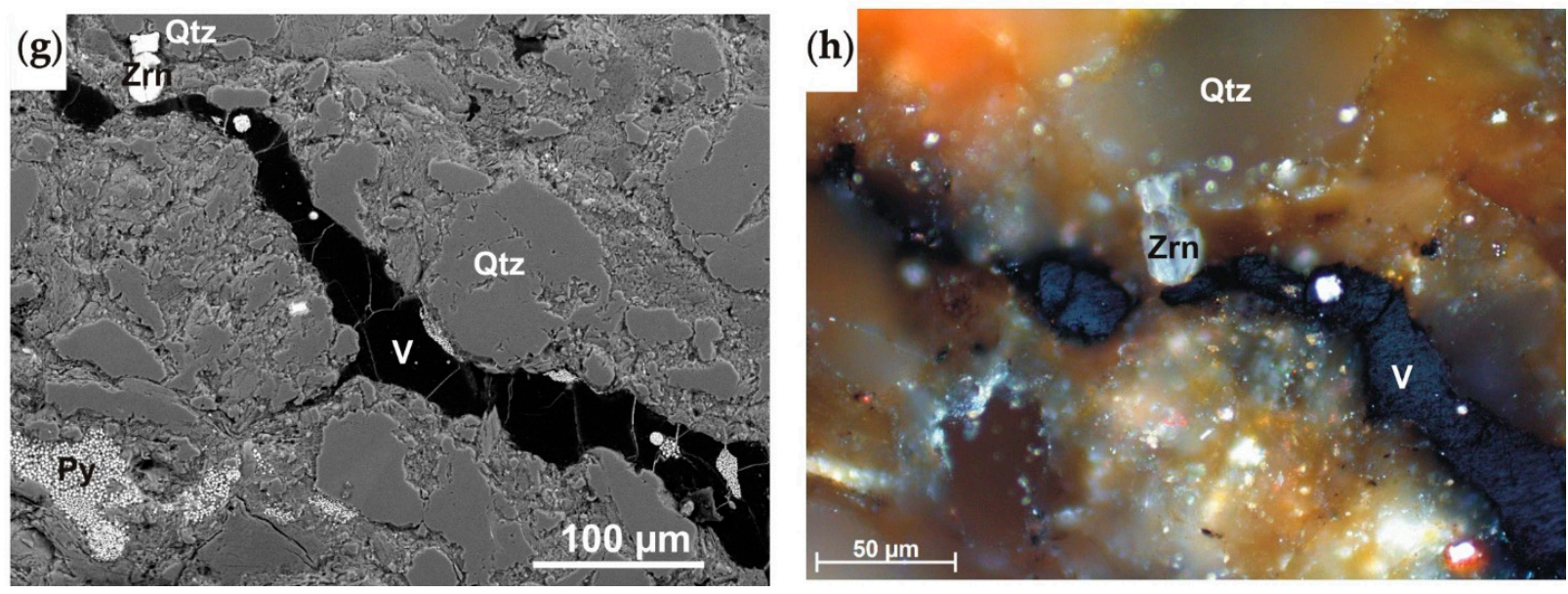

Figure 5. Back-scattered electron BSE (a,c,e,g) and reflected light optical microscopy RLOM (b,d,f,h) images of samples collected in the northern part of the Jas-Mos mining area. (a) Veins filled with ( $\mathrm{Mg}, \mathrm{Fe}) \mathrm{CO}_{3}(\mathrm{Mg}$-Sd) and quartz (Qtz) in vitrinite (V). Framboidal pyrite (Py) and accessory monazite (Mnz) are present. Right yellow rectangle is enlarged in (b), left rectangle in (c) and (d). (b) Quartzitic-carbonatic veinlets in vitrinite. (c,d) Secondary anatase (Ant) and halite (Hl) among quartz, muscovite (Ms) and clay minerals. (e,f) Framboidal pyrite partly replaced by hematite (Hem). (g,h) Accessory zircon (Zrn) detected by SEM-EDS and visible in RLOM image. Sample N6.
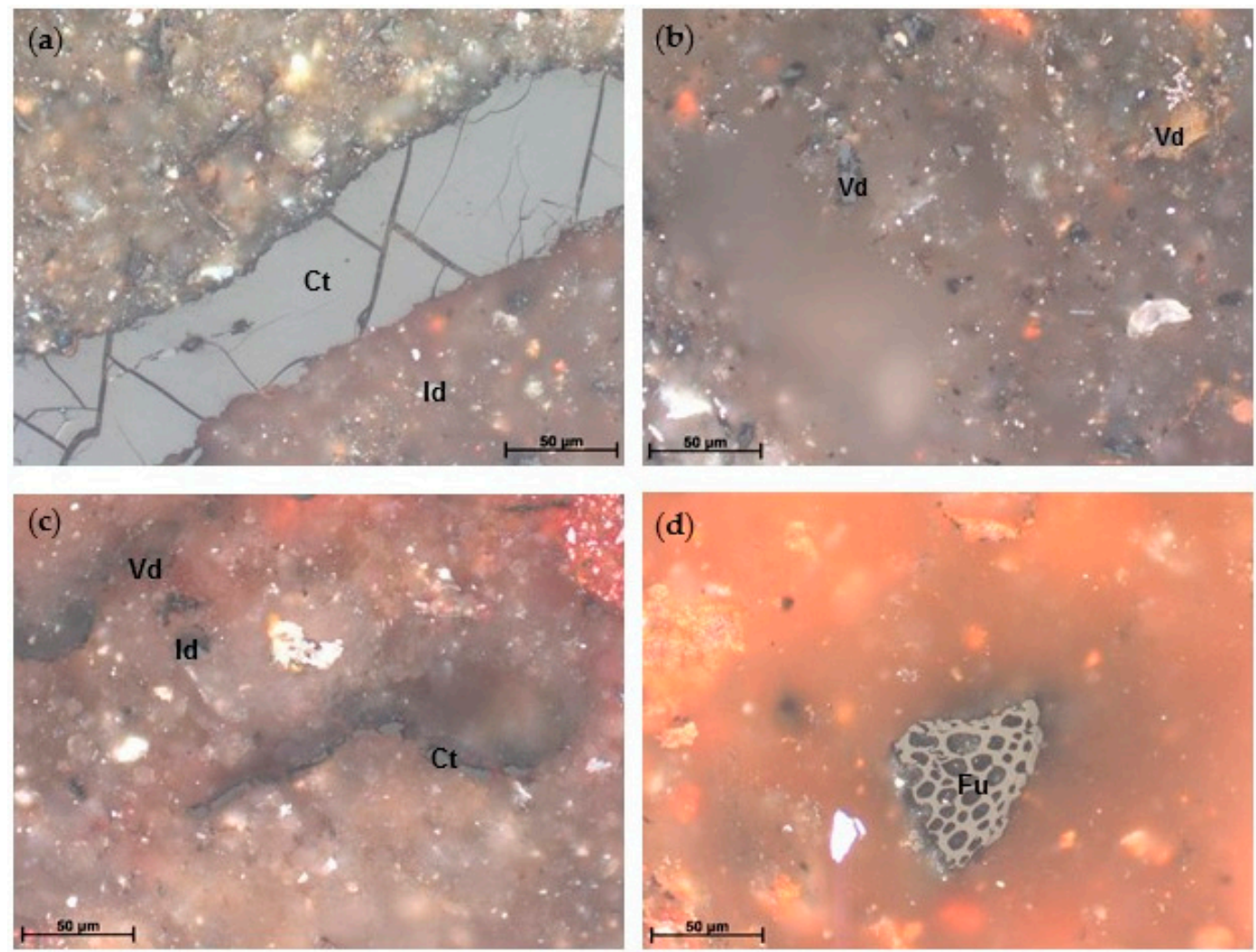

Figure 6. Macerals present in gangue rocks associated with disappearing coal seams in the northern and southern parts of the Jas-Mos mining area. (a) Collotelinite (Ct) with perpendicular cracks, sample N1; (b) vitrodetrinite (Vd), sample N3; (c) cracked collotelinite $(\mathrm{Ct})$, vitrodetrinite $(\mathrm{Ct})$ and inertodetrinite $(\mathrm{Id})$, sample S2; (d) fusinite (Fu), sample S4. Reflected white light, immersion oil. 

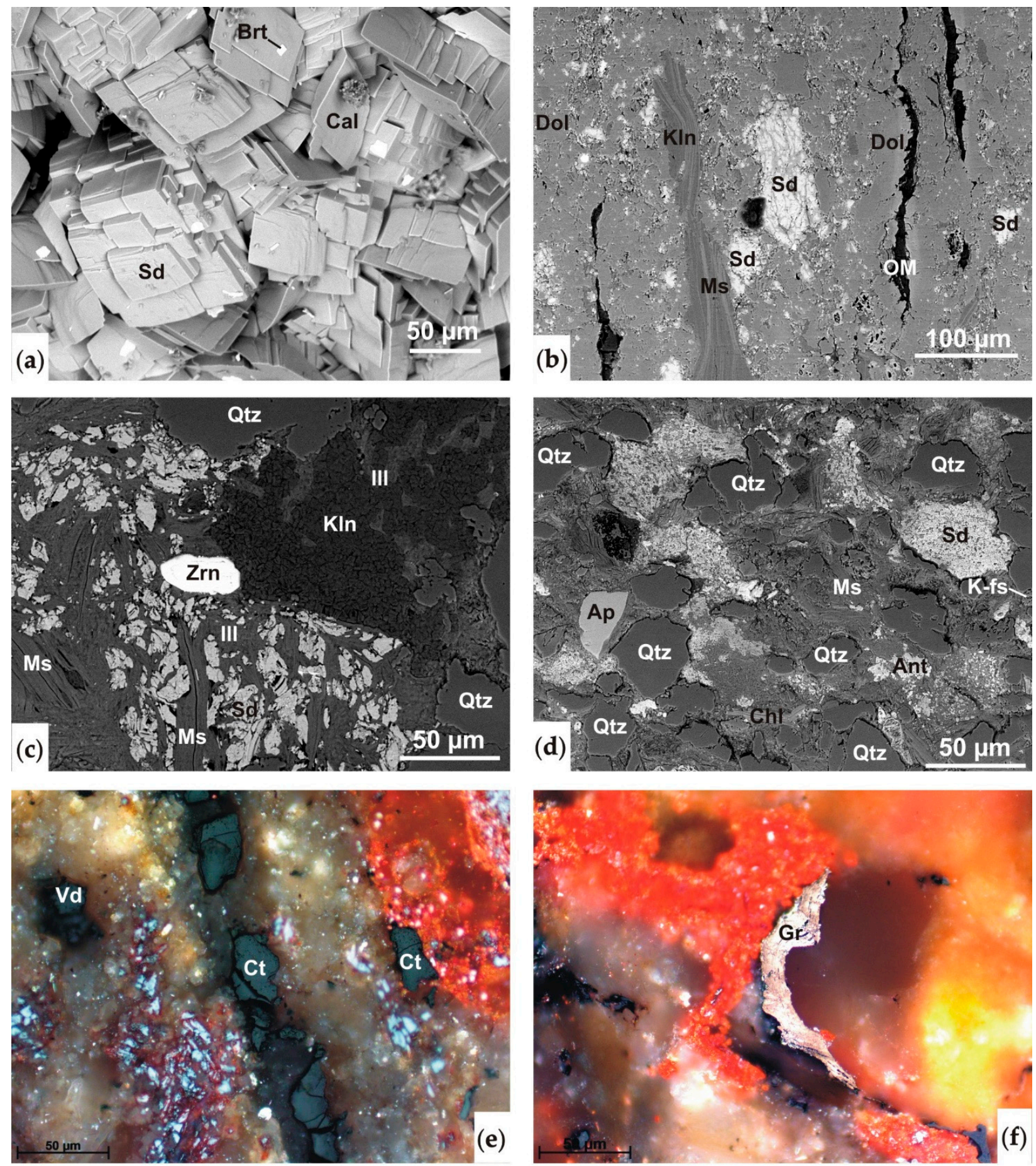

Figure 7. Back-scattered electron BSE (a-d) and reflected light optical microscopy RLOM (e-f) images of samples collected in the southern part of the Jas-Mos mining area. (a) Siderite (Sd) rhombohedra, calcite (Cal) and barite (Brt) occurring in fractures in sample S1; (b) carbonates impregnating the gangue rock with dolomite (Dol) forming veins along the organic matter (OM) and kaolinite (Kln) and muscovite (Ms) form interlayers in sample S2; (c) quartz (Qtz), muscovite, kaolinite, illite (Ill), siderite and accessory zircon (Zrn) in sample S3; (d) secondary hydroxylapatite (Ap), anatase (Ant) among quartz, K-feldspars (K-fs), muscovite, Fe-chlorite (Chl), siderite and clay minerals in sample S5; (e) cracked collotelinite (Ct) and vitrodetrinite (Vd) particle in mineral matter in sample S3; (f) graphitized carbon in sample S4.

\subsection{Mineralogy and Chemistry}

The mineral composition of gangue rocks is typical for siltstones in the USCB $[7,26,42]$ that, apart from organic matter, mainly consist of primary quartz, muscovite/illite, kaolinite 
and $\mathrm{Mg}>\mathrm{Fe}$ chlorite. Averaged amounts are shown in Table 2 and Figures 5 and 7. Apart from the kaolinite contents, which are similar everywhere, amounts of illite and chlorite are higher in samples from the northern side of the Jas-Mos mining area, with quartz dominating on the southern side. Na- and K-feldspars, carbonates such as calcite, dolomite, siderite or siderite-magnesite, framboidal pyrite and accessory zircon, monazite and xenotime are subordinate (Figures 5 and 7; Table 2). These minerals are all of sedimentary and detrital origin. Other minerals, i.e., hematite, goethite, barite, cristobalite-tridymite, halite, anatase, hydroxylapatite, alunite, alunogen, $\mathrm{ZnS}$ and elemental lead, can reflect low-temperature heating [20-23,43-45]. The xenomorphic habit of most is indicative of primary-mineral substitution or, as with anatase, secondary crystallization (Figure $5 \mathrm{c}, \mathrm{d}$ ). Halite, quartz and Fe-Mg carbonate form veinlets in sample N6 (Figure 5). Carbonates dominate in samples from the southern part, impregnating the rocks or crystallizing in fractures (Figure 7).

Chemical composition depends on the mineral contribution [45-47]. Main-element contents represent siltstone composition, apart from S2 rich in carbonates and S3 and S4 rich in quartz. The reddish color in the south is due to dispersed hematite. Trace-element concentrations reflect their affinity to the main minerals present, such as $\mathrm{Rb}$ to $\mathrm{K}$ in illite, and the occurrence of tiny grains of chalcopyrite, $\mathrm{ZnS}$ or elemental $\mathrm{Pb}$ (Table 3).

Table 2. Mineral compositions of the gangue-rocks samples from the northern (N1-N8) and southern (S1-S6) parts of the Jas-Mos mining area. Averaged content of mineral phases of the northern $(\mathrm{N})$ and southern $(\mathrm{S})$ samples is calculated. Higher values are shown in bold.

\begin{tabular}{|c|c|c|c|c|c|c|c|c|c|c|c|c|c|c|c|c|}
\hline Mineral Phase & N1 & N2 & N3 & N4 & N5 & N6 & N7 & N8 & S1 & S2 & S3 & $\mathrm{S} 4$ & S5 & S6 & $\mathbf{N}$ & $\mathrm{S}$ \\
\hline Quartz $\mathrm{SiO}_{2}$ & 30 & 29 & 35 & 41 & 29 & 25 & 30 & 36 & 30 & 21 & 74 & 70 & 37 & 56 & 32 & 48 \\
\hline $\begin{array}{c}\text { Illite/muscovite } \\
\mathrm{KAl}_{2}\left(\mathrm{AlSi} i_{3} \mathrm{O}_{10}\right)(\mathrm{OH})_{2}\end{array}$ & 38 & 34 & 31 & 40 & 39 & 38 & 38 & 36 & 41 & 4 & 7 & 3 & 50 & 5 & 37 & 18 \\
\hline $\begin{array}{l}\text { Kaolinite group } \\
\mathrm{Al}_{2}\left(\mathrm{Si}_{2} \mathrm{O}_{5}\right)(\mathrm{OH})_{4}\end{array}$ & 14 & 13 & 10 & 12 & 10 & 4 & 9 & 8 & & 22 & 6 & 23 & $\operatorname{tr}$ & 13 & 10 & 11 \\
\hline $\begin{array}{c}\text { Chlorite } \\
\left(\mathrm{Mg}_{\mathrm{g}} \mathrm{Fe}^{2+}\right)_{5} \mathrm{Al}\left(\mathrm{AlSi}_{3} \mathrm{O}_{10}\right)(\mathrm{OH})_{8}\end{array}$ & 17 & 19 & 20 & 4 & 21 & $\operatorname{tr}$ & 19 & 12 & 10 & & & 2 & & & 14 & 2 \\
\hline Hematite $\mathrm{Fe}_{2} \mathrm{O}_{3}$ & $\operatorname{tr}$ & $\operatorname{tr}$ & $\operatorname{tr}$ & $\operatorname{tr}$ & & $\operatorname{tr}$ & & $\operatorname{tr}$ & $\operatorname{tr}$ & 13 & $\operatorname{tr}$ & 1 & 2 & 3 & $\operatorname{tr}$ & 3 \\
\hline Cristobalite-tridimite $\mathrm{SiO}_{2}$ & & 1 & 2 & 2 & 2 & & 1 & 1 & & & & & & 9 & 1 & 2 \\
\hline $\mathrm{K}$-feldspar $\mathrm{K}_{2} \mathrm{AlSi}_{3} \mathrm{O}_{8}$ & & & & & & 32 & & & 11 & & 6 & & 6 & & 4 & 4 \\
\hline $\mathrm{Na}$-feldspar $\mathrm{Na}_{2} \mathrm{AlSi}_{3} \mathrm{O}_{8}$ & & & & & & & & & 6 & $\operatorname{tr}$ & & & 3 & & 0 & 2 \\
\hline Calcite $\mathrm{CaCO}_{3}$ & 1 & & $\operatorname{tr}$ & 1 & $\operatorname{tr}$ & & 1 & 1 & $\operatorname{tr}$ & & 2 & & & & 1 & $\operatorname{tr}$ \\
\hline Dolomite $\mathrm{CaMg}\left(\mathrm{CO}_{3}\right)_{2}$ & & & & & & & & & & 27 & 2 & 2 & & & 0 & 5 \\
\hline Siderite $\mathrm{FeCO}_{3}$ & 1 & 1 & & & & & & & $\operatorname{tr}$ & 4 & 2 & & & & $\operatorname{tr}$ & 1 \\
\hline Siderite-magnesite $(\mathrm{Fe}, \mathrm{Mg}) \mathrm{CO}_{3}$ & $\operatorname{tr}$ & & 1 & 1 & & $\operatorname{tr}$ & 1 & 2 & 2 & 5 & & $\operatorname{tr}$ & & & 1 & 1 \\
\hline Zircon $\mathrm{ZrSiO}_{4}$ & & $\operatorname{tr}$ & $\operatorname{tr}$ & $\operatorname{tr}$ & & $\operatorname{tr}$ & $\operatorname{tr}$ & $\operatorname{tr}$ & & $\operatorname{tr}$ & $\operatorname{tr}$ & & $\operatorname{tr}$ & $\operatorname{tr}$ & $\operatorname{tr}$ & $\operatorname{tr}$ \\
\hline Monazite $\mathrm{CePO}_{4}$ & $\operatorname{tr}$ & & & $\operatorname{tr}$ & & $\operatorname{tr}$ & $\operatorname{tr}$ & $\operatorname{tr}$ & & & $\operatorname{tr}$ & & $\operatorname{tr}$ & $\operatorname{tr}$ & $\operatorname{tr}$ & $\operatorname{tr}$ \\
\hline Xenotime $\mathrm{YPO}_{4}$ & & & & & & $\operatorname{tr}$ & $\operatorname{tr}$ & $\operatorname{tr}$ & & & & & & & $\operatorname{tr}$ & 0 \\
\hline Chalcopyrite $\mathrm{CuFeS} 2$ & $\operatorname{tr}$ & & & & & & & $\operatorname{tr}$ & & & & & & & $\operatorname{tr}$ & 0 \\
\hline Pyrite $\mathrm{FeS}_{2}$ & & $\operatorname{tr}$ & $\operatorname{tr}$ & & & $\operatorname{tr}$ & $\operatorname{tr}$ & $\operatorname{tr}$ & & $\operatorname{tr}$ & & & & & $\operatorname{tr}$ & $\operatorname{tr}$ \\
\hline Organic matter & & $\operatorname{tr}$ & $\operatorname{tr}$ & $\operatorname{tr}$ & & $\operatorname{tr}$ & $\operatorname{tr}$ & $\operatorname{tr}$ & $\operatorname{tr}$ & $\operatorname{tr}$ & & & & $\operatorname{tr}$ & $\operatorname{tr}$ & $\operatorname{tr}$ \\
\hline Halite $\mathrm{NaCl}$ & & & & & & $\operatorname{tr}$ & & & & & & & & & $\operatorname{tr}$ & 0 \\
\hline Anatase $\mathrm{TiO}_{2}$ & $\operatorname{tr}$ & $\operatorname{tr}$ & $\operatorname{tr}$ & $\operatorname{tr}$ & $\operatorname{tr}$ & $\operatorname{tr}$ & $\operatorname{tr}$ & 1 & & 4 & & $\operatorname{tr}$ & $\operatorname{tr}$ & & 0.2 & 0.7 \\
\hline Alunite $\mathrm{KAl}_{3}\left(\mathrm{SO}_{4}\right)_{2}(\mathrm{OH})_{6}$ & & 2 & 2 & & & & 2 & & & & & & 2 & & 0.8 & 0.3 \\
\hline Alunogen $\mathrm{Al}_{2}\left(\mathrm{SO}_{4}\right)_{3} \cdot 17 \mathrm{H}_{2} \mathrm{O}$ & & & & & & & & & & & & & & 16 & 0 & 2.7 \\
\hline $\mathrm{ZnS}$ & $\operatorname{tr}$ & $\operatorname{tr}$ & & $\operatorname{tr}$ & & & $\operatorname{tr}$ & $\operatorname{tr}$ & & & & & & & $\operatorname{tr}$ & 0 \\
\hline Berlinite? $\mathrm{AlPO}_{4}$ & $\operatorname{tr}$ & & & & & & & & & & & & & & $\operatorname{tr}$ & 0 \\
\hline Barite $\mathrm{BaSO}_{4}$ & & & & $\operatorname{tr}$ & $\operatorname{tr}$ & & $\operatorname{tr}$ & $\operatorname{tr}$ & $\operatorname{tr}$ & $\operatorname{tr}$ & & & & $\operatorname{tr}$ & $\operatorname{tr}$ & $\operatorname{tr}$ \\
\hline Goethite $\alpha-F e^{3+} O(O H)$ & & $\operatorname{tr}$ & & & & & & & & $\operatorname{tr}$ & & 2 & & & $\operatorname{tr}$ & 0.4 \\
\hline Hydroxylapatite $\mathrm{Ca}_{5}\left(\mathrm{PO}_{4}\right)_{3}(\mathrm{OH})$ & $\operatorname{tr}$ & $\operatorname{tr}$ & & $\operatorname{tr}$ & $\operatorname{tr}$ & $\operatorname{tr}$ & $\operatorname{tr}$ & 3 & $\operatorname{tr}$ & & $\operatorname{tr}$ & $\operatorname{tr}$ & $\operatorname{tr}$ & & 0.5 & $\operatorname{tr}$ \\
\hline Murashkoite? FeP & & $\operatorname{tr}$ & & & & & & & & & & & & & $\operatorname{tr}$ & 0 \\
\hline Pb elemental & & & & & & & & $\operatorname{tr}$ & & & & & & & $\operatorname{tr}$ & 0 \\
\hline
\end{tabular}


Table 3. Chemical composition of the gangue-rocks samples from the northern (N1-N8) and southern (S1-S6) parts of the Jas-Mos mining area (in ppm, except where otherwise indicated) with averaged $\mathrm{N}$ and $\mathrm{S}$. Increased values are marked in bold, lowered, in italics.

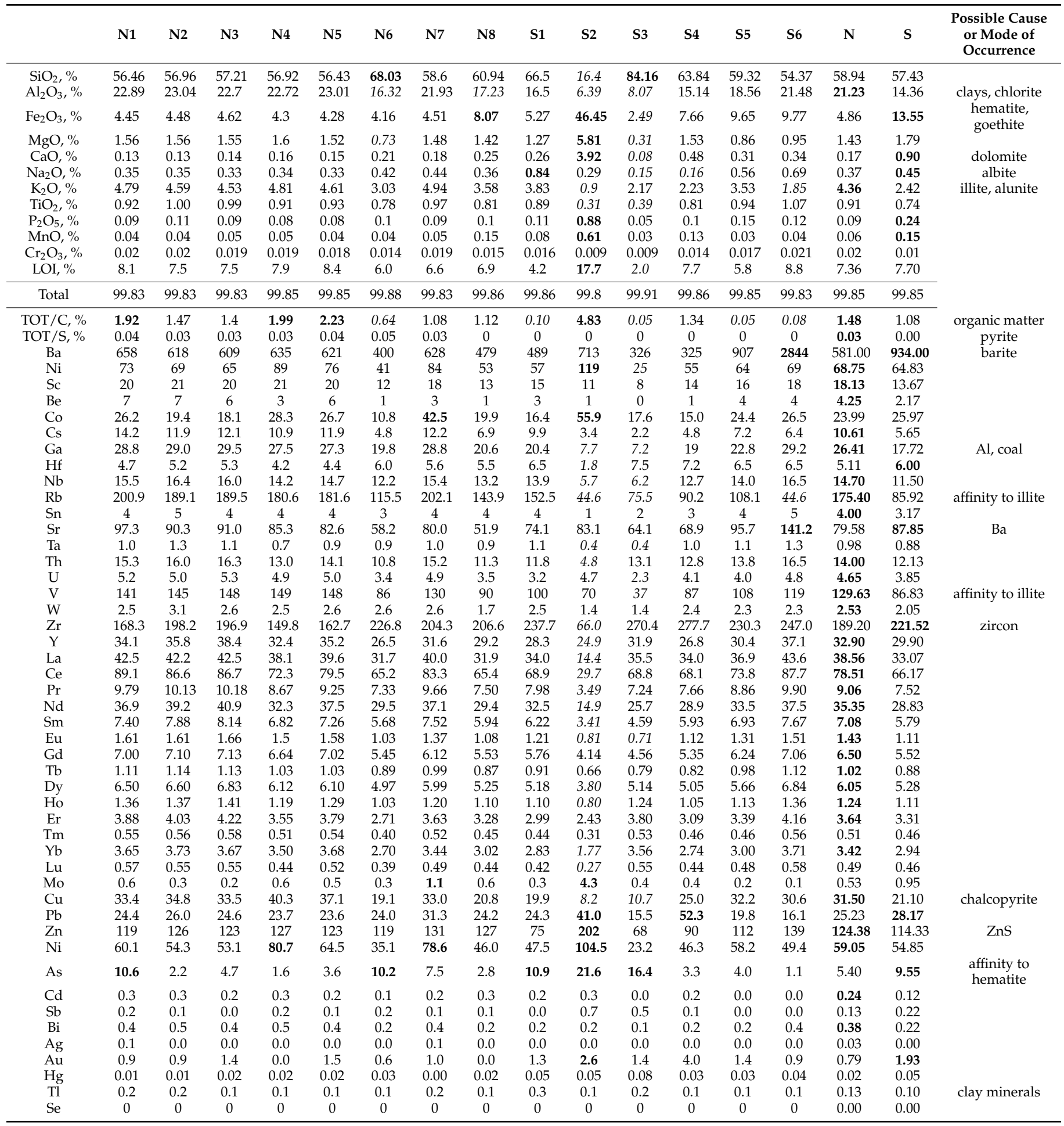

\subsection{Palynology}

Almost all positive palynological samples from both localities contain typical Upper Carboniferous miospores and plant debris (Figure 8) [48]. Samples (N1-N5, N7 and N8) from the northern area are more or less uniformly differentiated taxonomically; Crassispora kosnakei is the most common miospore, accompanied by less numerous Cirratrira- 
dites saturnii, Cingulizonates bialatus, Convolutispora sp., Densosporites spp., Florinites spp., Granulatisporites sp., Lycospora pusilla, Kraeuselisporites sp., Punctatisporites spp., Raistrickia microhorrida, Savitrisporites nux, Schulzospora sp. and a single Tripartites sp. The rest of the organic material in these samples consists of a mixture of melanogen (non-translucent) and hylogen (translucent) particles. The exception is sample N8 with mainly black palynodebris (melanogen); rarely were miospores noted as single taxa only.
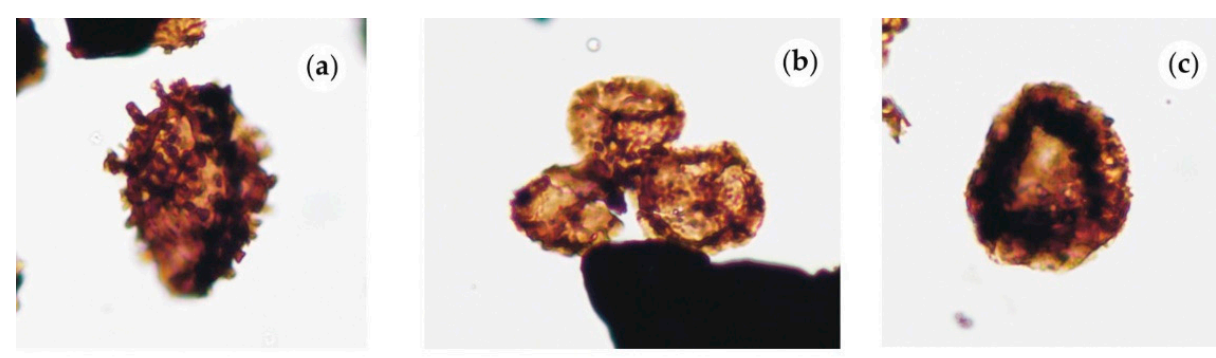

(c)

(d)
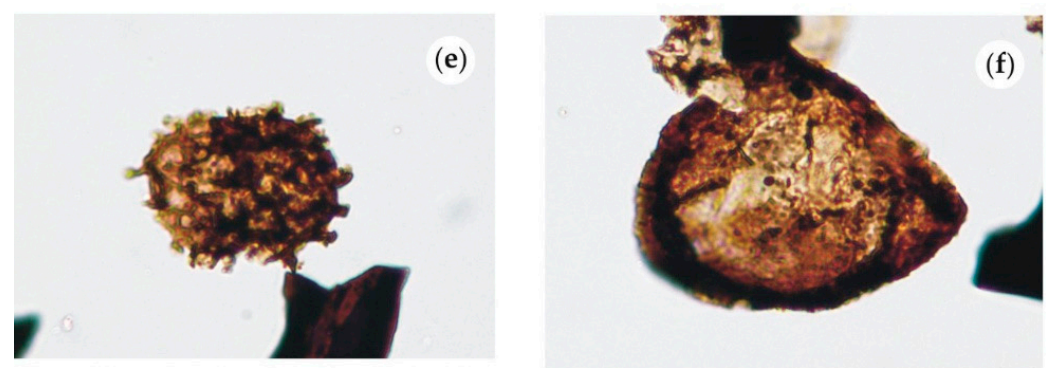

)

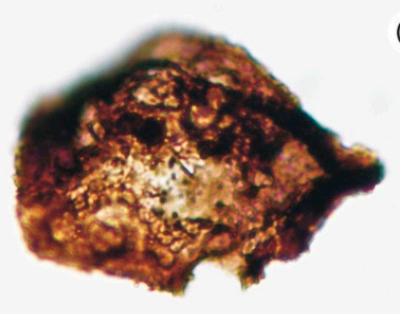

$(\mathrm{g})$

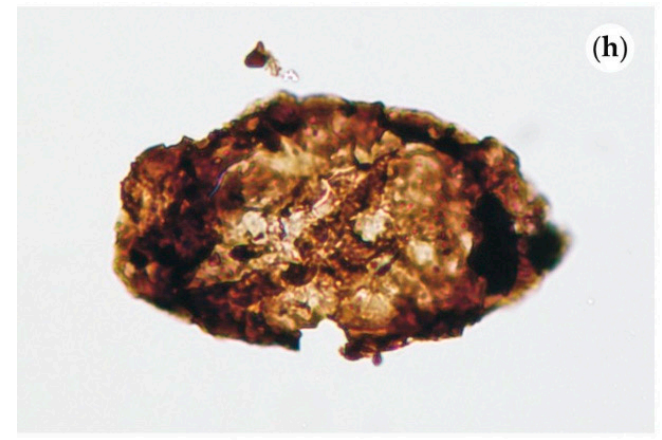

)

(i)

(j)
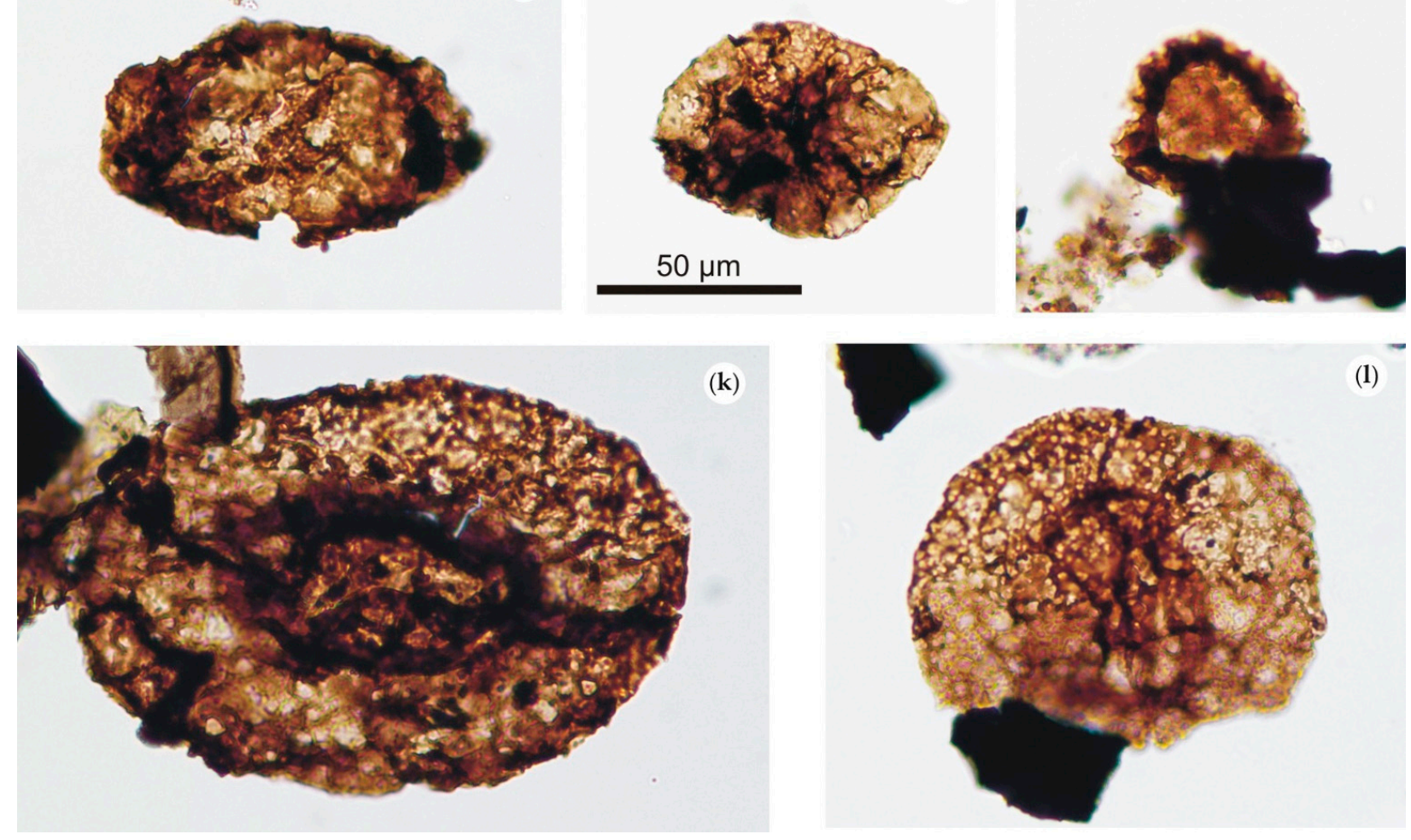

Figure 8. Microflora present in samples from northern (N samples) and southern (S samples) areas of the Jas-Mos mining area. (a) Raistrickia saetosa, sample N5; (b) Lycospora pusilla?, sample N5; (c) Cingulizonates sp., sample N5; (d) Tripartites sp., sample S4; (e) Raistrickia saetosa, sample N1; (f) Crassispora kosankei, sample N1; (g) Crassispora kosankei, sample S4; (h) Schulzospora sp., sample N1; (i) Florinites sp., sample S4; (j) Cingulizonates bialatus, sample N8; (k) Florinites cf. visendus., sample N1; (1) Florinites cf. pumicosus., sample S2. Scale bar is the same for all images. 
Samples S2 and S4 from the southern area possess fewer miospores and taxonomically differentiated taxa assemblages. Identified miospores are Crassispora kosankei, Florinites sp., Lycospora pusilla, Raistrickia sp., Schulzospora sp. and Triprtites sp. Miospores were more common in S4, than in sample S2. The predominant fraction of organics in S4 consists of melanogen with, less commonly, hylogen and residual AOM (Figure 9). The organic content of $\mathrm{S} 2$ is dominated by melanogen.
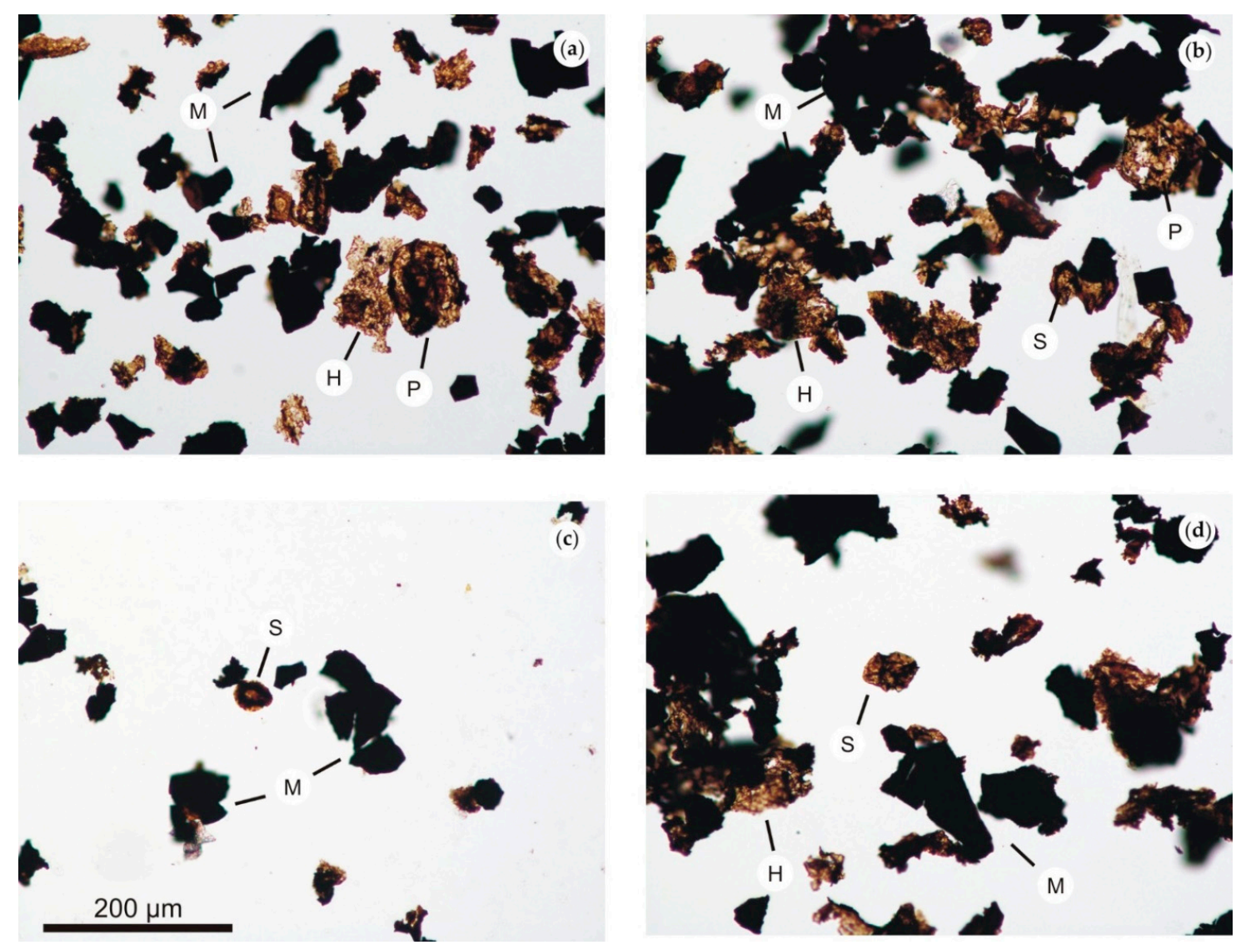

Figure 9. Palynofacies from northern (N samples) and southern (S samples) areas. (a) Sample N1; (b) sample N3; (c) sample S4; (d) sample S4. H, hylogen; M, melanogen; S, spora; P, pollen; AOM, amorphous organic matter. Scale bar is the same for all images.

The organic matter from both areas shows a high degree of degradation. Almost all organic components, especially the exines of the miospores, exhibit numerous traces left by recrystallizing minerals (Figure 8).

Disperse organic matter is often used as a thermal indicator. The exines of miospores change color with rising temperature and based on the palynoflora coloration, it is possible to estimate the thermal maturity of hosting sediments [49,50]. Importantly, miospore thermal scales are tentatively correlated with the Ro scale [51]. The brown-dark brown color of exines from the northern area fall between 5 and 6 on Batten's TAS scale [49]; the color, which is more or less the same in all analyzed samples, correlates with the 1-1.5 interval on the Ro scale. The color of the microflora in the southern area is similar and allows correlation with the same Ro interval. On this basis, the paleotemperature can be estimated to have been $100-150{ }^{\circ} \mathrm{C}$.

\subsection{Organic Geochemistry}

There are significant differences in the organic matter characteristics of the two investigated rock series, i.e., the red-orange series and the dark grey series with red streaks or 
patches. Extraction yields range from 0.0008 wt.\% to $0.0580 \mathrm{wt}$ \% $\%$, with the latter series showing 10 times higher extractability (Table 1). Though extracts of both series contained the same wide range of biomarkers, such as n-alkanes, alkylcyclohexanes, acyclic isoprenoids (pristane and phytane), steranes, tri- and pentacyclic triterpanes, distributions of a given compound group are distinctly different in both. Aromatic hydrocarbons together with their aliphatic derivatives comprise compounds from rare naphthalene $(\mathrm{m} / \mathrm{z}=128)$ or phenanthrene $(m / z=178)$ up to 6-ring PAHs, such as coronene $(m / z=300)$ and dibenzopyrenes $(m / z=302)$.

\section{Biomarker Occurrence and Distributions}

$n$-Alkanes $(m / z=71)$, in the range $n-C_{15}-n-C_{33}$, show a monomodal distribution with a smooth outline for the reddish samples and a bimodal distribution type for the grey samples (Figure 10). The latter is similar to $n$-alkane distributions found in Upper Silesia bituminous coals or accompanying rocks; it is common in mature organic matter of terrestrial origin. In addition, values of the Carbon Preference Index fit those found for USCB organic matter, i.e., 1.50 on average [16,52]. However, the $n$-alkane distributions in the reddish-rock extracts are more unusual in showing a smooth Gaussian-type outline, closer to pyrolytical $n$-alkane distributions found in coal pyrolysates or coal-waste rocks subjected to self-heating $[53,54]$. CPI values are also slightly lower for the reddish rocks at 1.30 , on average, though it seems that long-chain $n$-alkanes still preserve the primary pattern of distribution and the Gaussian hump is located in the short-chain $n$-alkanes range. The maximum Gaussian hump is slightly different in different southern samples, i.e., at $n$ $\mathrm{C}_{18}$ for $\mathrm{S} 2$ and $n-\mathrm{C}_{21}-n-\mathrm{C}_{22}$ for the remainder. Such variation can be due to different degrees of heating affecting organic matter, whether by a paleofire or an intrusion; coal-waste rocks subjected to self-heating show the same feature $[55,56]$.

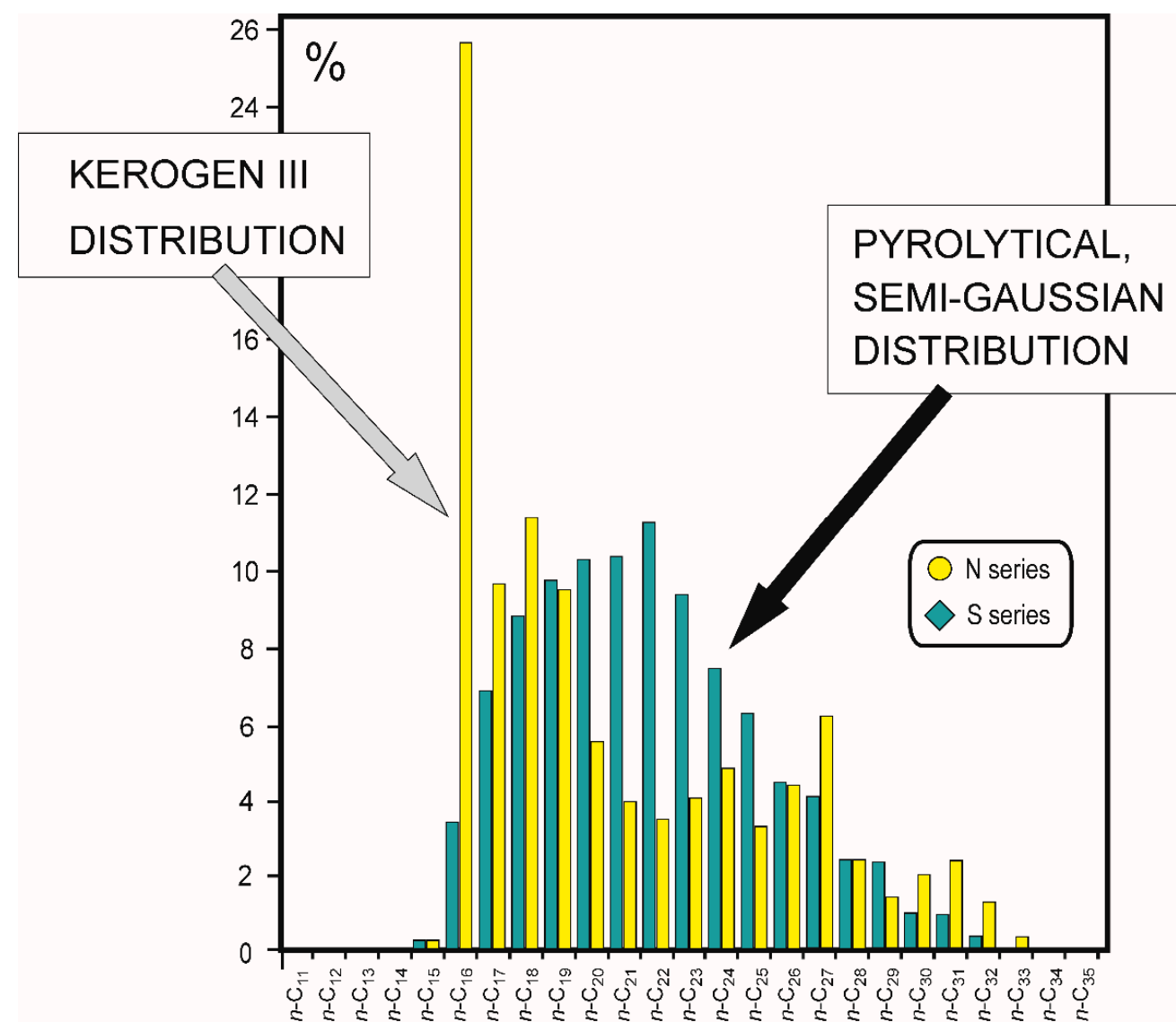

Figure 10. Comparison of $n$-alkane profiles from the northern and southern parts of the Jas-Mos mining area with changes caused by heating indicated. 
The same differences in $\mathrm{Pr} / \mathrm{Ph}$ values are apparent in both sample sets, which are low ( 0.52 on average) in the reddish rocks, but for grey rocks reach values (2.02) common for USCB bituminous coals [16,52]. It is possible that thermal stress caused rapid preferential expulsion of lighter compounds, such as $\mathrm{Pr}$, from the kerogen macromolecule, decreasing $\mathrm{Pr} / \mathrm{Ph}$ values. A decrease in $\mathrm{Pr} / \mathrm{Ph}$ values with increasing thermal maturity can occur with organic matter evolution within a deposit [57]. Moreover, preferential expulsion of lighter $n$-alkanes is confirmed by lowered $\mathrm{Pr} / n-\mathrm{C}_{17}, \mathrm{Ph} / n-\mathrm{C}_{18}$ and $(\mathrm{Pr}+\mathrm{Ph}) /\left(n-\mathrm{C}_{17}+n-\mathrm{C}_{18}\right)$ values (Table 4; Figure 11). However, the variability of values of these ratios is high and the general ranges of $\mathrm{Pr} / n-\mathrm{C}_{17}$ and $\mathrm{Ph} / n-\mathrm{C}_{18}$ in Figure 10 overlap. Assuming that the grey rocks better retain the unaltered values of the ratios, Figure 10 indicates that organic matter was deposited in a dysoxic estuarine or lagoonal environment at a high to normal water level and kerogen is mostly of II/III type. However, the influence of heating, as seen in the case of the reddish rocks that plot in the field of much more mature organic matter and, likewise, with some grey samples, may indicate a shift due to paleofires.

The $n$-alkane- and acyclic-isoprenoid results seem to indicate more advanced changes in the reddish samples, but this is not so when the distributions of steranes $(\mathrm{m} / z=217)$ and pentacyclic triterpanes $(m / z=191)$ are compared. Excepting N6 and N7, these latter compounds are almost absent in the grey rocks, in which they were possibly destroyed by heat, whereas they occur in all reddish rocks. The range of pentacyclic triterpanes comprises compounds such as $18 \alpha(\mathrm{H})-22,29,30$-trisnorneohopane (abbreviation: Ts), $17 \alpha(\mathrm{H})-22,29,30$ trisnorhopane (Tm) and a series of $\mathrm{C}_{29}$ to $\mathrm{C}_{33} 17 \alpha(\mathrm{H}), 21 \beta(\mathrm{H})$ hopanes ( $\alpha \beta$ hopanes), accompanied by a few moretanes ( $\beta \alpha$ hopanes), in much lower concentrations than $\alpha \beta$ hopanes (Figure 12). Hopanes with a biological $\beta \beta$ configuration were not identified. Short distributions ending at $C_{33}$ pentacyclic triterpanes are common in coals and kerogen III [57]. Whenever pentacyclic triterpanes occur in the extracts, the distribution types are similar to each other and are characteristic of thermally mature organic matter at the middle catagenesis stage at least.

Table 4. Extraction yields and biomarker ratios indicative of maturity and biogenic origin.

\begin{tabular}{|c|c|c|c|c|c|c|c|c|c|c|c|c|}
\hline $\begin{array}{l}\text { Sample } \\
\text { No }\end{array}$ & $\underset{(1)}{\Sigma 2 / \Sigma 1}$ & $\begin{array}{l}\text { CPI } \\
(2)\end{array}$ & $\begin{array}{c}\mathrm{Pr} / \mathrm{Ph} \\
\text { (3) }\end{array}$ & $\begin{array}{c}\mathrm{Pr} / \mathrm{C}_{17} \\
\text { (4) }\end{array}$ & $\begin{array}{c}\mathrm{Ph} / \mathrm{C}_{18} \\
\text { (5) }\end{array}$ & $\underset{(6)}{\mathrm{Ts} /(\operatorname{Tm}}+\mathrm{Ts})$ & $\begin{array}{c}C_{30} \beta \alpha / \\
(\alpha \beta+\beta \alpha) \\
(7)\end{array}$ & $\begin{array}{c}C_{30} \beta \beta / \\
(\beta \beta+\alpha \beta+\beta \alpha) \\
(8)\end{array}$ & $\begin{array}{c}\mathrm{C}_{31} \mathrm{~S} / \\
(\mathrm{S}+\mathrm{R}) \\
(9) \\
\end{array}$ & $\begin{array}{c}\mathrm{C}_{30} \mathrm{~S} / \\
(\mathrm{S}+\mathrm{R}) \\
(10)\end{array}$ & $\begin{array}{c}\mathrm{C}_{29} \alpha \beta \beta / \\
(\alpha \alpha \alpha+\alpha \beta \beta) \\
(11)\end{array}$ & $\begin{array}{c}\mathrm{C}_{29} / \mathrm{C}_{27} \\
(12)\end{array}$ \\
\hline N1 & 0.58 & 0.98 & 2.02 & 0.59 & 0.77 & - & - & - & - & 0.34 & 0.14 & 0.66 \\
\hline N2 & 0.56 & 1.98 & 1.06 & 0.83 & 1.20 & - & - & - & - & & & \\
\hline N3 & 1.16 & 1.40 & 0.55 & 0.91 & 1.65 & - & - & - & - & 0.33 & 0.47 & 0.93 \\
\hline N4 & 0.38 & 1.66 & 2.01 & 0.61 & 0.61 & - & - & - & - & - & - & - \\
\hline N5 & 0.50 & 1.26 & 1.15 & 0.56 & 0.56 & - & - & - & - & - & - & - \\
\hline N6 & 0.44 & 1.85 & 0.64 & 0.81 & 0.97 & 0.35 & 0.39 & 0.17 & 0.37 & 0.35 & 0.28 & 1.01 \\
\hline N7 & 0.92 & 1.55 & 1.42 & 1.94 & 0.76 & 0.39 & 0.37 & 0.08 & 0.64 & - & - & - \\
\hline N8 & 0.56 & 1.25 & 0.28 & 0.64 & 1.12 & - & - & - & - & - & - & - \\
\hline $\mathrm{S} 1$ & 0.73 & 1.11 & 0.58 & 0.69 & 0.74 & 0.30 & 0.20 & 0.05 & 0.52 & 0.37 & 0.41 & 0.80 \\
\hline S2 & 0.19 & 1.65 & 0.38 & 0.32 & 0.67 & 0.34 & 0.19 & 0.12 & 0.54 & 0.38 & 0.41 & 0.63 \\
\hline S3 & 1.59 & 1.19 & 0.59 & 0.56 & 0.64 & 0.34 & 0.15 & 0.04 & 0.55 & 0.37 & 0.49 & 1.07 \\
\hline $\mathrm{S} 4$ & 1.38 & 1.14 & 0.62 & 0.75 & 0.84 & 0.24 & 0.00 & 0.00 & 0.48 & - & - & - \\
\hline S5 & 0.98 & 1.30 & 0.56 & 0.77 & 0.92 & 0.39 & 0.29 & 0.04 & 0.56 & 0.34 & 0.48 & 0.81 \\
\hline S6 & 0.97 & 1.42 & 0.59 & 0.78 & 0.91 & 0.53 & 0.39 & 0.09 & 0.54 & 0.36 & 0.48 & 0.72 \\
\hline average $\mathrm{N}$ & 0.64 & 1.49 & 1.14 & 0.86 & 0.95 & 0.37 & 0.38 & 0.12 & 0.50 & 0.34 & 0.30 & 0.87 \\
\hline average $S$ & 0.97 & 1.30 & 0.55 & 0.64 & 0.79 & 0.36 & 0.20 & 0.06 & 0.53 & 0.36 & 0.45 & 0.81 \\
\hline
\end{tabular}

(1) $\Sigma 2 / \Sigma 1=\left[\Sigma\left(\right.\right.$ from $n-\mathrm{C}_{23}$ to $\left.\left.n-\mathrm{C}_{37}\right)\right] /\left[\Sigma\left(\right.\right.$ from $n-\mathrm{C}_{11}$ to $\left.\left.n-\mathrm{C}_{22}\right)\right] ; m / z=71$, source indicator [58]. (2) $\mathrm{CPI}=0.5\left\{\left[\left(n-\mathrm{C}_{25}+n-\mathrm{C}_{27}+n-\mathrm{C}_{29}+\right.\right.\right.$ $\left.\left.n-\mathrm{C}_{31}+n-\mathrm{C}_{33}\right) /\left(n-\mathrm{C}_{24}+n-\mathrm{C}_{26}+n-\mathrm{C}_{28}+n-\mathrm{C}_{30}+n-\mathrm{C}_{32}\right)\right]+\left[\left(n-\mathrm{C}_{25}+n-\mathrm{C}_{27}+n-\mathrm{C}_{29}+n-\mathrm{C}_{31}+n-\mathrm{C}_{33}\right) /\left(n-\mathrm{C}_{26}+n-\mathrm{C}_{28}+n-\mathrm{C}_{30}+n-\mathrm{C}_{32}+n-\mathrm{C}_{34}\right)\right] ;$ Carbon Preference Index; $m / z=71$, thermal maturity parameter [59]. (3) $\mathrm{Pr} / \mathrm{Ph}=$ pristane/phytane; parameter of environment oxicity (with exception of coals), $m / z=71$ [60]. (4) $\mathrm{Pr} / n-\mathrm{C}_{17}=$ pristane $/ n$-heptadecane; $m / z=71$ [61]. (5) $\mathrm{Ph} / n$ - $\mathrm{C}_{18}=\mathrm{phytane} / n$-octadecane; $m / z=71$ [61]. (6) Ts / (Ts+Tm) = 18 $\alpha(\mathrm{H})$-22,29,30-trisnorneohopane/ $(18 \alpha(\mathrm{H})-22,29,30$-trisnorneohopane $+17 \alpha(\mathrm{H})-22,29,30$-trisnorhopane); $m / z=191$, thermal maturity parameter [57]. (7) $\mathrm{C}_{30} \beta \alpha /(\alpha \beta+\beta \alpha)=17 \beta(\mathrm{H}), 21 \alpha(\mathrm{H})-29$-hopane $\mathrm{C}_{30} /\left(17 \alpha(\mathrm{H}), 21 \beta(\mathrm{H})-29-\mathrm{hopane} \mathrm{C}_{30}+\right.$ $17 \beta(\mathrm{H}), 21 \alpha(\mathrm{H})$-29-hopane $\left.\mathrm{C}_{30}\right) ; m / z=191$, thermal maturity parameter [62]. (8) $\mathrm{C}_{30} \beta \beta /(\beta \beta+\alpha \beta+\beta \alpha)=17 \beta(\mathrm{H}), 21 \mathrm{~b}(\mathrm{H})-29-\mathrm{hopane} \mathrm{C}_{30} /$ $\left(17 \beta(\mathrm{H}), 21 \mathrm{~b}(\mathrm{H})-29\right.$-hopane $\mathrm{C}_{30}+17 \beta(\mathrm{H}), 21 \alpha(\mathrm{H})$-29-hopane $\mathrm{C}_{30}+17 \mathrm{a}(\mathrm{H}), 21 \mathrm{~b}(\mathrm{H})$-29-hopane $\left.\mathrm{C}_{30}\right) \mathrm{m} / \mathrm{z}=191$, thermal maturity parameter $[62]$. (9) $\mathrm{C}_{31} \mathrm{~S} /(\mathrm{S}+\mathrm{R})=17 \alpha(\mathrm{H}), 21 \beta(\mathrm{H})$-29-homohopane $22 \mathrm{~S} /(17 \alpha(\mathrm{H}), 21 \beta(\mathrm{H})$-29-homohopane $22 \mathrm{~S}+17 \alpha(\mathrm{H}), 21 \beta(\mathrm{H})-29$-homohopane $22 \mathrm{R})$; $m / z=191$, thermal maturity parameter [57]. (10) $C_{29} S /(S+R)=$ a ratio of $C_{29}-5 \alpha, 14 \alpha, 17 \alpha(H)$-stigmastane 20S to a sum of its diastereomers $20 S$ and 20R; $m / z=217$ [62]. (11) $C_{29} \alpha \alpha \alpha /\left(C_{29} \alpha \alpha \alpha+C_{29} \alpha \beta \beta\right)=$ a ratio of $C_{29}-5 \alpha, 14 \alpha, 17 \alpha(\mathrm{H})$-stigmastane (20S $\left.+20 \mathrm{R}\right)$ to a sum of its distereomers $\mathrm{C}_{29}-5 \alpha, 14 \alpha, 17 \alpha(\mathrm{H})$-stigmastane $(20 \mathrm{~S}+20 \mathrm{R})+\mathrm{C}_{29}-5 \alpha, 14 \beta, 17 \beta(\mathrm{H})$-stigmastane $(20 \mathrm{~S}+20 \mathrm{R}) ; m / z=217$, thermal maturity parameter [62]. (12) $C_{29} / C_{27}=$ a sum of $C_{29}$ sterane diastereomers/a sum of $C_{27}$ sterane diastereomers; $m / z=217$, biological input [63]. 


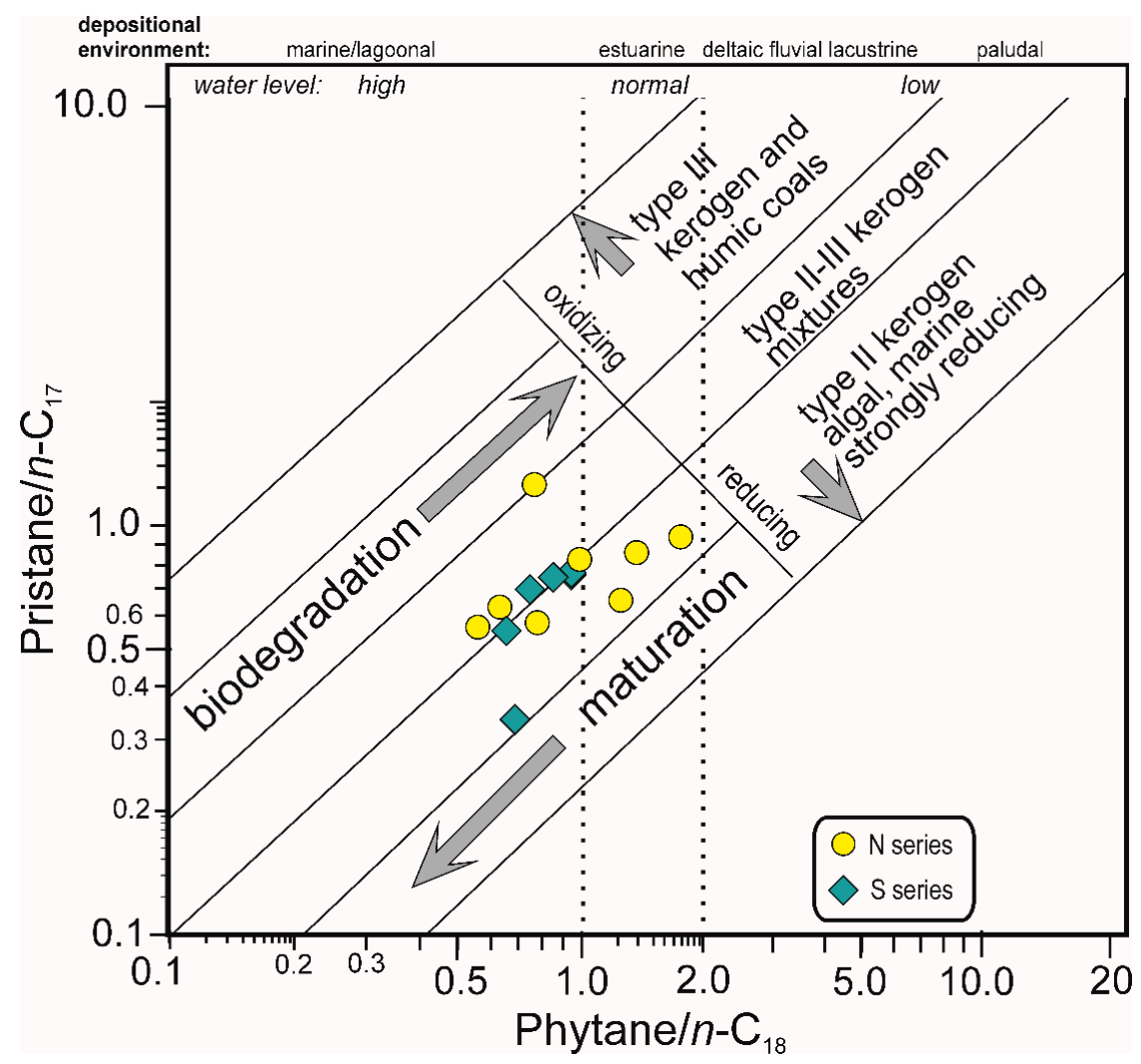

Figure 11. $\mathrm{Pr} / n-\mathrm{C}_{17}$ versus $\mathrm{Ph} / n-\mathrm{C}_{18}$ diagram. $\mathrm{Pr}$, pristane; $\mathrm{Ph}$, phytane.

Several thermal maturity ratios based on pentacyclic triterpanes were calculated (Table 4). Values of Ts $/\left(\mathrm{Ts}+\mathrm{Tm}\right.$ ) lie in the range of $0.24-0.53$ (average 0.37 ) and $\mathrm{C}_{31} \mathrm{~S} /$ $(\mathrm{S}+\mathrm{R})$ in the range of $0.36-0.64$ (average 0.52$)$. In most extracts, $\mathrm{C}_{31} \mathrm{~S} /(\mathrm{S}+\mathrm{R})$ values lie close to 0.57 . This value, considered to mark the end of the validity of this ratio, corresponds to middle catagenesis $\left(R_{o}>0.8\right)$. Ts $/(T s+T m)$ seems to be surprisingly low for such mature samples and does not fit the range (0.71-0.91) of USCB bituminous coals [52]. It has been shown that both Ts and Tm can be destroyed during coal combustion or self-heating with preferred Ts over Tm removal due, possibly, to the lesser resistance of the former to oxidation and/or heat $[56,64,65]$, thereby decreasing Ts/(Ts $+\mathrm{Tm})$ values. However, such behavior is opposite to that shown during catagenesis of organic matter within a deposit, where $T m$ tends to decrease with increasing maturity, causing $\mathrm{Ts} / \mathrm{Ts}+\mathrm{Tm})$ values to increase up to $\sim 0.80$ at the end of catagenesis [57]. As natural maturation causes $\mathrm{Tm}$ to Ts conversion rather than thermal destruction of Tm, the discrepancy between low Ts/ Ts + $\mathrm{Tm}$ ) values compared to much higher maturity indicated by other maturity ratios are likely related to rapid thermal stress rather than to low maturity.

As with pentacyclic triterpane ratios, sterane distributions and values of steranebased ratios do not differ in both samples sets. Steranes and diasteranes were present in low concentrations and their distributions are dominated by cholestanes ( 42rel\%). This indicates a deltaic/open sea depositional environment rather than coal swamp, as shown in Figure 13, and agrees with the assessment of the sedimentary environment based on Pr and Ph ratios $[57,63]$. The cholestane predominance differentiates the investigated samples from USCB coals, whose sterane distribution is usually dominated by stigmastanes $\left(\mathrm{C}_{29}\right.$ steranes), pointing to decreased input of terrestrial plant material compared to coals. Diasteranes $(m / z=259)$, diagenetic products of sterols formed in the presence of clay minerals, occur in much lower concentrations in the samples than do steranes in the extracts and their distributions also show the prevalence of $\mathrm{C}_{27}$ diasteranes. 


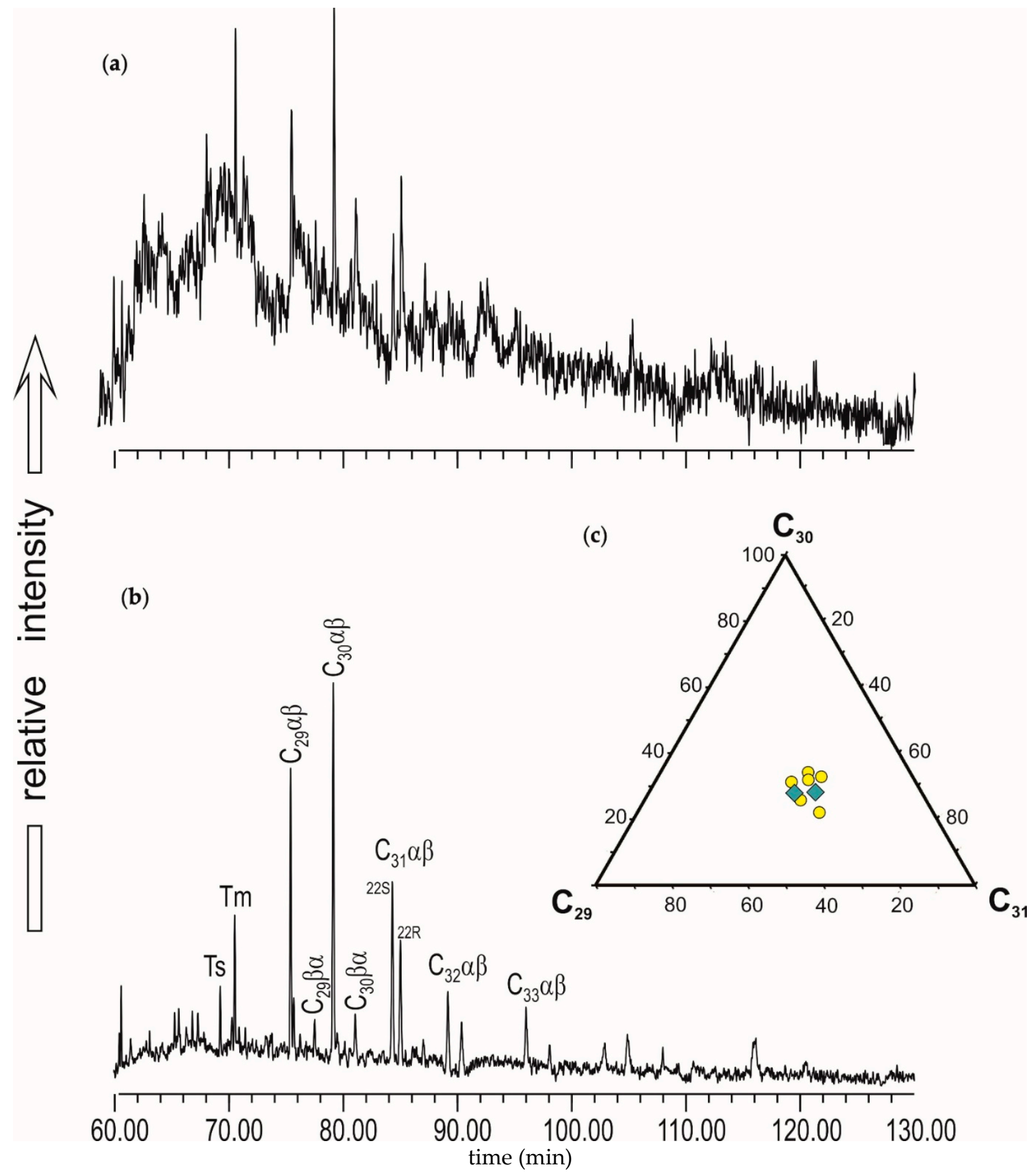

Figure 12. Pentacyclic triterpanes distributions in: (a) sample N6; (b) sample S3; (c) ternary diagram of $C_{29}-C_{30}-C_{31}$ relative percentages. Ts, $18 \alpha(\mathrm{H})$-22,29,30-trisnorneohopane; Tm, $17 \alpha(\mathrm{H})$-22,29,30-trisnorhopane; $\mathrm{C}_{29} \alpha \beta, 17 \alpha(\mathrm{H}), 21 \beta(\mathrm{H})$ 29-norhopane; $C_{29} \beta \alpha, 17 \beta(\mathrm{H}), 21 \alpha(\mathrm{H})$-29-norhopane; $\mathrm{C}_{30} \alpha \beta, 17 \alpha(\mathrm{H}), 21 \beta(\mathrm{H})$-29-hopane; $\mathrm{C}_{30} \beta \alpha, 17 \beta(\mathrm{H}), 21 \alpha(\mathrm{H})-29$ hopane; $\mathrm{C}_{31} \alpha \beta, 17 \alpha(\mathrm{H}), 21 \beta(\mathrm{H})$-29-homohopane; $\mathrm{C}_{32} \alpha \beta, 17 \alpha(\mathrm{H}), 21 \beta(\mathrm{H})$-29-bishomohopane, $\mathrm{C}_{33} \alpha \beta, 17 \alpha(\mathrm{H}), 21 \beta(\mathrm{H})-29$ trishomohopane. Yellow circle: $\mathrm{N}$ series; blue box: $\mathrm{S}$ series. 


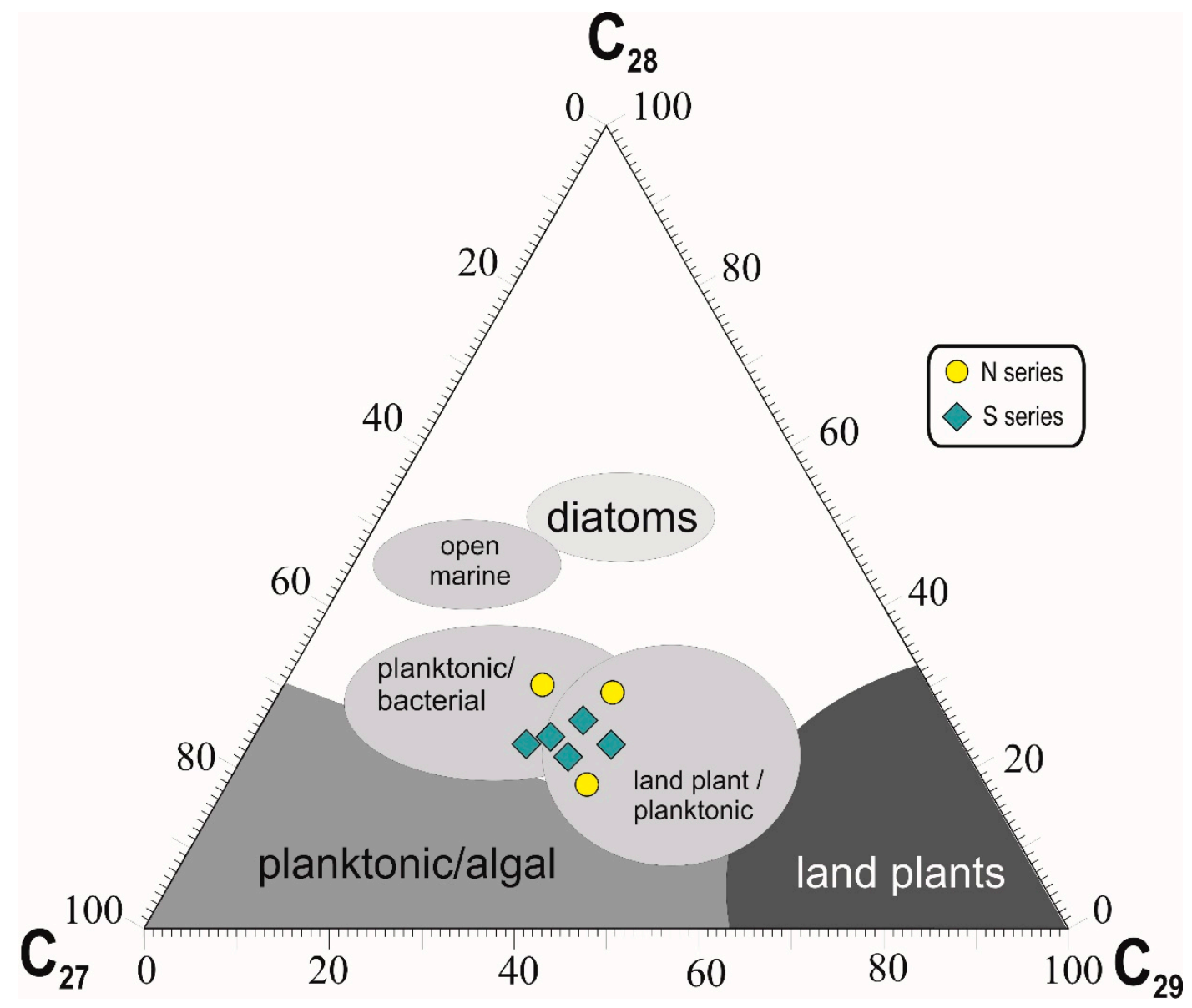

Figure 13. Ternary diagram of relative percentage of cholestanes $\left(C_{27}\right)$, ergostanes $\left(C_{28}\right)$ and stigmastanes $\left(C_{29}\right)$.

Values of sterane maturity ratios, i.e., the ratio of $5 \alpha, 14 \beta, 17 \beta(\mathrm{H})$-stigmastanes to the sum of all stigmastane diastereomers $\left(C_{29} \alpha \alpha \alpha /(\alpha \alpha \alpha+\alpha \beta \beta)\right)$ and the ratio of $C_{29}$ $5 \alpha, 14 \alpha, 17 \alpha(\mathrm{H})$-stigmastane $20 \mathrm{~S}$ to the sum of its diastereomers 20S and 20R [62] (Table 4) are in similar ranges for both reddish and grey samples, averaging 0.37 and 0.35 , respectively. These values accord with values previously found for USBC bituminous coals [52]. The limited changes in values of pentacyclic triterpene and sterane ratios caused by heating allow better assessment of the geochemical features of primary organic matter prior to any heating event than is possible with $n$-alkanes.

\section{Polycyclic Aromatic Hydrocarbons}

The aromatic compounds comprise unsubstituted polycyclic aromatic hydrocarbons (PAHs) with 2-7 aromatic rings in a molecule that includes naphthalene $(\mathrm{m} / \mathrm{z}=128)$, biphenyl $(m / z=168)$, phenanthrene and anthracene $(m / z=178)$, phenylnaphthalene $(\mathrm{m} / \mathrm{z}=204)$, fluorene and pyrene $(\mathrm{m} / \mathrm{z}=202)$, benzo(ghi)fluorene, benzo(a)anthracene, trifenylene and chrysene $(\mathrm{m} / \mathrm{z}=228)$, benzofluoranthenes, benzopyrenes and perylene $(m / z=252)$, benzo(ghi)perylene, anthanthrene and indeno[1,2,3-cd]pyrene $(m / z=276)$, dibenzoanthracenes, benzochrysene and picene $(\mathrm{m} / z=278)$, coronene $(\mathrm{m} / z=300)$ and dibenzopyrenes $(m / z=302)$. All unsubstituted PAHs are accompanied by their alkyl derivatives and partially aromatized compounds. Dominating heterocyclic aromatic compounds are mostly oxygen derivatives.

Lighter 2-ring PAHs (naphthalene and biphenyl) are absent in most of the extracts of both sample groups. Phenanthrene is the PAH predominating in all samples. Low anthracene contents $(\sim 0.5 \mathrm{rel} \%)$ point to pyrolytical conditions rather than fire open to oxygen. The significant difference between the reddish and grey rocks is that, in the former, 
contents of PAHs with increasing numbers of aromatic rings decrease, whereas, in the latter, contents of 6-7-ring PAHs, mostly dibenzopyrenes, increase. These compounds are rare in USCB coals and, if present, occur in trace amounts.

Dibenzopyrene isomers and coronene occur in diverse matrixes, such as coal tar [66], coal fly ash [67], cigarette smoke condensates [68], soils [69,70], sediments, diesel and gasoline vehicle emissions [68,71,72], air particulate matter [72] and waste incinerator emissions [73]. In all these occurrences, they are considered to be related to pyrolysis or incomplete organic matter combustion. Moreover, these PAHs are common in soot [74-76]. Though they occur in all $\mathrm{N}$ and $\mathrm{S}$ samples, in extracts of the former, their contents are twice as high on average, than in the $S$ extracts (Table 4 ).

Distributions of PAHs groups with 2-3, 4-5 and 6-7 condensed rings show elevated contents of the heaviest PAHs, compared to USCB bituminous coals analyzed previously [52]. The different distribution patterns distinguishing the $\mathrm{N}$ and $\mathrm{S}$ sample sets are also seen in the distribution of PAHs (Figure 14).

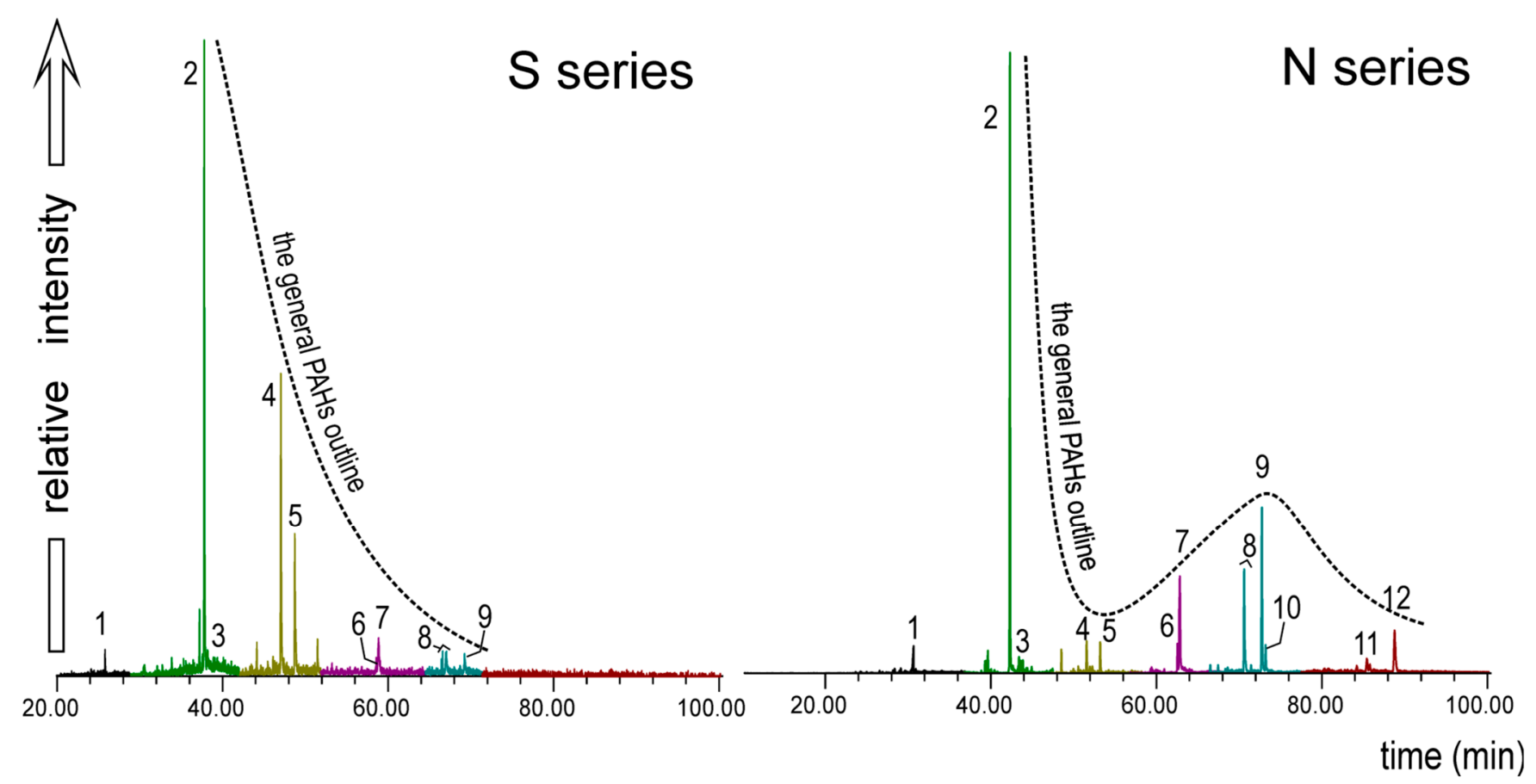

Figure 14. Two types of polycyclic aromatic hydrocarbons distributions. Peaks identification: 1: naphthalene, 2: phenanthrene, 3: anthracene, 4: fluoranthene, 5: pyrene, 6: benzo(a)anthracene, 7: chrysene, 8: benzofluoranthenes, 9: benzo(a)pyrene, 10: benzo(e)pyrene, 11: benzo(ghi)perylene, and 12: indeno[1,2,3-cd]pyrene.

\section{Alkyl Derivatives of Lighter Aromatic Hydrocarbons}

Lighter aromatic hydrocarbons include alkyl derivatives of naphthalene, biphenyl, anthracene, phenanthrene, chrysene and pyrene. To assess the thermal influence on the organic matter, the following ratios of alkyl aromatic hydrocarbons were calculated: methylnaphthalene ratio (MNR), dimethylnaphthalene ratio (DNR), trimethylnalphthalene ratios (TNR-1, TNR-2 and TNR-5), methylphenanthrene indices (MPI-1 and MPI-3), a sum of methylphenanthrenes to phenanthrene (MP/P), dimethylphenanthrene ratio (DMPR), a sum of dimethylphenanthrenes to phenanthrene (DMP/P), methylpyrene ratios (MPyR1 and MPyR2), methylfluorene index (MFI) and methylfluorene ratio (MFR) (Table 5). Based on MPI-1 values, calculated vitrinite reflectance $\left(R_{c}\right)$ values were determined for comparison with measured values $\left(R_{r}\right)$ [77-79].

When the average values in both sample sets are compared, all thermal maturity ratios show higher values for the grey samples than the reddish samples, e.g., MNR $=2.29$ and 1.59, respectively; DNR $=7.78$ and 3.63, MPI- $1=0.79$ and 0.38, $\mathrm{MPy} 1=1.08$ and 0.39 
(Table 5). As Figures 15 and 16 show, there are distinctive differences between both sets in the relative contents of alkyl naphthalene and phenanthrene isomers used in calculating these ratios. Since these ratios are built based on variability in isomer resistance to increasing temperature, the ratio values will increase with increasing heat, due to the thermal evolution of organic matter in a deposit, or due to magmatic intrusion or internal fire [78].

According to the Shapiro-Wilk test, the values of aromatic hydrocarbon ratios showed normal distribution, except the MFR values set. Thus, the Pearson correlation has been applied to calculate the square of the Pearson product moment correlation to find whether there is a linear correlation between selected ratios. Linear correlations between various aromatic hydrocarbon maturity ratios confirm that both sample sets were initially of the same maturity and similar in type of organic matter. Correlation coefficient values of 0.3376 0.4664 indicate weak correlations for DMPR versus MPI-1, MPI-3 and MP/P and values of $0.6040-0.7350$, moderate to strong positive correlations for MPy-1 versus MPI-1, MPI-3 and MP/P (Figure 17). Negative correlations (from -0.6059 to -0.8079 ) between MFR and MPI-1, MPI-3 and MP/P reflect the fact that the MFR decreases with increasing maturity.

In Figure 17, values for the red and grey samples show minimal overlap. The higher maturity of the grey rocks is indicated. Aromatic hydrocarbon maturity ratios appear to be more sensitive than biomarker ratios to short-term thermal influences; unlike the former, pentacyclic triterpene and sterane ratios do not show significant differences. In organic matter, the biomarker ratios preserve initial geochemical features due to earlier catagenesis and mild long-term heating. Except for Ts and Tm, they did not register later higher-temperature thermal stresses of short duration. Thus, the aliphatic biomarkers and alkyl aromatic hydrocarbons enable discrimination between earlier catagenic stages of organic-matter evolution and local changes due to any later intra-deposit heating.

Table 5. Aromatic hydrocarbons ratios indicative of maturity.

\begin{tabular}{|c|c|c|c|c|c|c|c|c|c|c|c|c|c|c|c|c|}
\hline & $\begin{array}{c}\text { MNR } \\
\text { (1) }\end{array}$ & $\begin{array}{l}\text { DNR } \\
\text { (2) }\end{array}$ & $\begin{array}{l}\text { TNR1 } \\
\text { (3) }\end{array}$ & $\begin{array}{l}\text { TNR2 } \\
\text { (4) }\end{array}$ & $\begin{array}{l}\text { TNR55 } \\
\text { (5) }\end{array}$ & $\begin{array}{c}\text { MPI-3 } \\
\text { (6) }\end{array}$ & $\begin{array}{l}\text { MPI-1 } \\
\text { (7) }\end{array}$ & $\begin{array}{c}\text { DMPR } \\
(8)\end{array}$ & $\begin{array}{l}\text { MPyR } \\
\text { (9) }\end{array}$ & $\begin{array}{c}\mathrm{Rc} \\
(\mathbf{1 0 )}\end{array}$ & $\begin{array}{c}\mathrm{MP} / \mathrm{P} \\
\mathbf{( 1 1 )}\end{array}$ & $\begin{array}{c}\mathrm{DMP} / \mathrm{P} \\
(\mathbf{1 2})\end{array}$ & $\begin{array}{c}\text { MPyI1 } \\
\text { (13) }\end{array}$ & $\begin{array}{c}\text { MPyI2 } \\
\text { (14) }\end{array}$ & $\begin{array}{c}\text { MFR } \\
\text { (15) }\end{array}$ & $\begin{array}{l}\text { MFI } \\
\text { (16) }\end{array}$ \\
\hline N1 & 2.84 & 9.92 & 2.32 & 1.12 & 0.26 & 2.17 & 1.40 & 0.63 & 0.57 & 1.24 & 1.27 & 0.50 & 1.13 & 0.89 & 0.12 & 0.76 \\
\hline N2 & 3.97 & 15.50 & 1.45 & 0.94 & 0.44 & 1.74 & 1.44 & 0.53 & 0.51 & 1.26 & 1.59 & 0.74 & 1.05 & 0.82 & 0.16 & 0.72 \\
\hline N3 & - & - & - & - & - & 1.43 & 1.05 & 0.75 & 0.52 & 1.03 & 1.17 & 0.52 & 0.92 & 0.56 & 0.15 & 0.61 \\
\hline N4 & - & - & - & - & - & 1.69 & 1.30 & 0.57 & 0.60 & 1.18 & 1.39 & 0.56 & 1.00 & 0.81 & 0.11 & 0.57 \\
\hline N5 & 0.88 & 2.28 & 1.69 & 1.00 & 0.52 & 1.97 & 1.33 & 0.54 & 0.58 & 1.20 & 1.28 & 0.58 & 1.23 & 0.82 & 0.09 & 0.59 \\
\hline N6 & 1.77 & 11.05 & 1.79 & 1.12 & 0.66 & 1.50 & 0.83 & 0.58 & 0.56 & 0.90 & 0.82 & 0.46 & 1.29 & 0.93 & 0.20 & 1.16 \\
\hline N7 & 1.97 & 4.27 & 2.21 & 1.20 & 0.51 & 2.18 & 1.15 & 0.53 & 0.53 & 1.09 & 0.98 & 0.32 & 1.08 & 0.73 & 0.19 & 1.06 \\
\hline N8 & - & 3.75 & 1.92 & 1.09 & 0.62 & 1.78 & 0.96 & 0.59 & 0.57 & 0.98 & 0.87 & 0.35 & 0.92 & 0.76 & 0.19 & 1.00 \\
\hline S1 & 2.11 & 2.82 & 1.04 & 0.85 & 0.48 & 1.35 & 0.76 & 0.42 & 0.44 & 0.86 & 0.79 & 0.74 & 0.55 & 0.86 & 0.51 & 1.92 \\
\hline S2 & - & - & - & - & - & 1.19 & 0.37 & 0.39 & 0.68 & 0.62 & 0.35 & 0.11 & 0.25 & 0.73 & - & - \\
\hline S3 & 1.45 & 2.41 & 1.02 & 0.87 & 0.53 & 0.99 & 0.57 & 0.39 & 0.58 & 0.74 & 0.68 & 0.49 & 0.47 & 0.89 & 0.56 & 2.58 \\
\hline S4 & 2.10 & 3.97 & 1.23 & 0.88 & 0.45 & 1.35 & 0.31 & 0.41 & 0.59 & 0.59 & 0.27 & 0.06 & 0.20 & 0.71 & 0.69 & 2.18 \\
\hline S5 & & & 1.18 & 1.00 & 0.58 & 1.23 & 0.73 & 0.45 & 0.50 & 0.84 & 0.80 & 0.59 & 0.49 & 0.75 & 0.56 & 2.21 \\
\hline S6 & 0.69 & 5.33 & 0.84 & 0.73 & 0.42 & 1.19 & 0.67 & 0.38 & 0.53 & 0.80 & 0.73 & 0.43 & 0.35 & 0.65 & 0.60 & 1.30 \\
\hline average $\mathrm{N}$ & 2.29 & 7.80 & 1.90 & 1.08 & 0.50 & 1.81 & 1.18 & 0.59 & 0.55 & 1.11 & 1.17 & 0.50 & 1.08 & 0.79 & 0.15 & 0.81 \\
\hline average $\mathrm{S}$ & 1.59 & 3.63 & 1.06 & 0.87 & 0.49 & 1.22 & 0.57 & 0.41 & 0.55 & 0.74 & 0.60 & 0.40 & 0.39 & 0.76 & 0.58 & 2.04 \\
\hline
\end{tabular}

(1) $\mathrm{MNR}=$ 2-methylnaphthalene/1-methylnaphthalene; $m / z=142$, thermal maturity parameter [78]. (2) DNR-1 = (2,6dimethylnaphthalene $+2,7$-dimethylnaphthalene) $/ 1,5$-dimethylnaphthalene; $m / z=156$, thermal maturity parameter [78]. (3) TNR 1 $=2,3,6$-trimethylnaphthalene/ $(1,3,5-+1,4,6$ - trimethylnaphthalene); $m / z=170$, thermal maturity parameter [80]. (4) TNR $2=(1,3,7-+2,3,6-$ trimethylnaphthalene) $/(1,3,5-+1,3,6-+1,4,6$-trimethylnaphthalene); $m / z=170$, thermal maturity parameter [78]. $(5)$ TNR $5=1,2,7+1,6,7-$ trimethylnaphthalene $/ 1,2,5$-trimethylnaphthalene; $m / z=170$, thermal maturity parameter, [78]. (6) MPI-3 = (2- + 3-methylphenanthrene) $/(1-$ + 9-methylphenanthrene) [78]. (7) MPI-1 = $1.5 \times(2-+3$-methylphenanthrene)/(phenanthrene + 1- + 9-methylphenanthrene) [78]. (8) DMPR = dimethylphenanthrene $(\mathrm{DMP})$ ratio $([3,5-+2,6-+2,7-\mathrm{DMP}] /[1,3-+3,9-+2,10-+3,10-+1,6-+2,9-+2,5-\mathrm{DMP}]) ; \mathrm{m} / \mathrm{z}=206$, thermal maturity parameter [78]. (9) MPyR = 2-methylpyrene/(1-methylpyrene + 2-methylpyrene); $m / z=216$, thermal maturity parameter [81]. (10) Rc (MPI-1) $=0.6 \times$ MPI-1 +0.40 [77]. (11) MP $/ \mathrm{P}=$ a sum of methylphenanthrenes to phenanthrene [82]. (12) $\mathrm{DMP} / \mathrm{P}=\mathrm{a}$ sum of dimethylphenanthrenes to phenanthrene [82]. (13) MPyI $1=3 \times 2$-methylpyrene/(pyrene + 1- + 4- methylpyrene) [83]. (14) MPyI $2=$ 2-methylpyrene/(1- + 4- methylpyrene) [81]. (15) MFR = 4-methylfluorene/1-methylfluorene, [78]. (16) MFI = a sum of methylfluorenes to 1-methylfluorene, [78]. 


\section{S series}
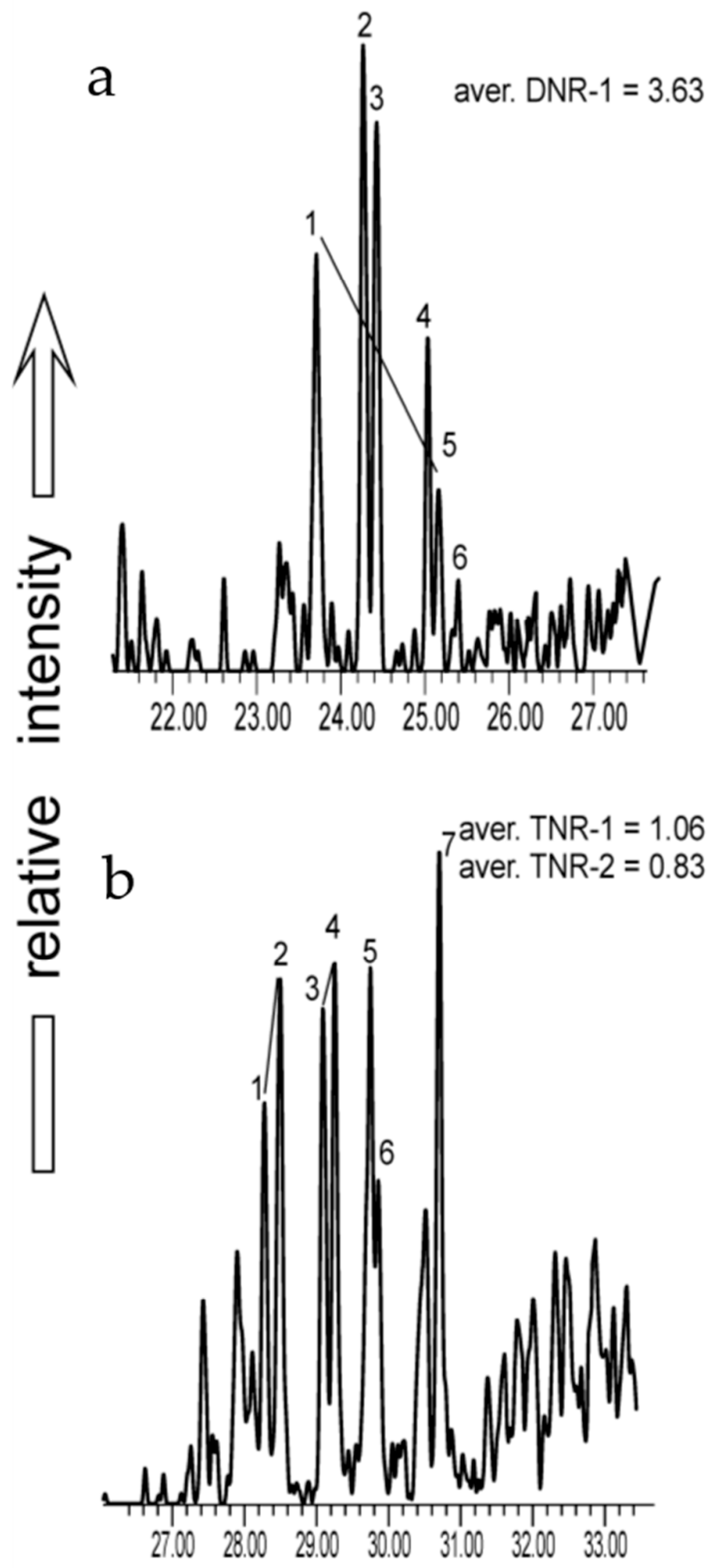

$\mathrm{N}$ series
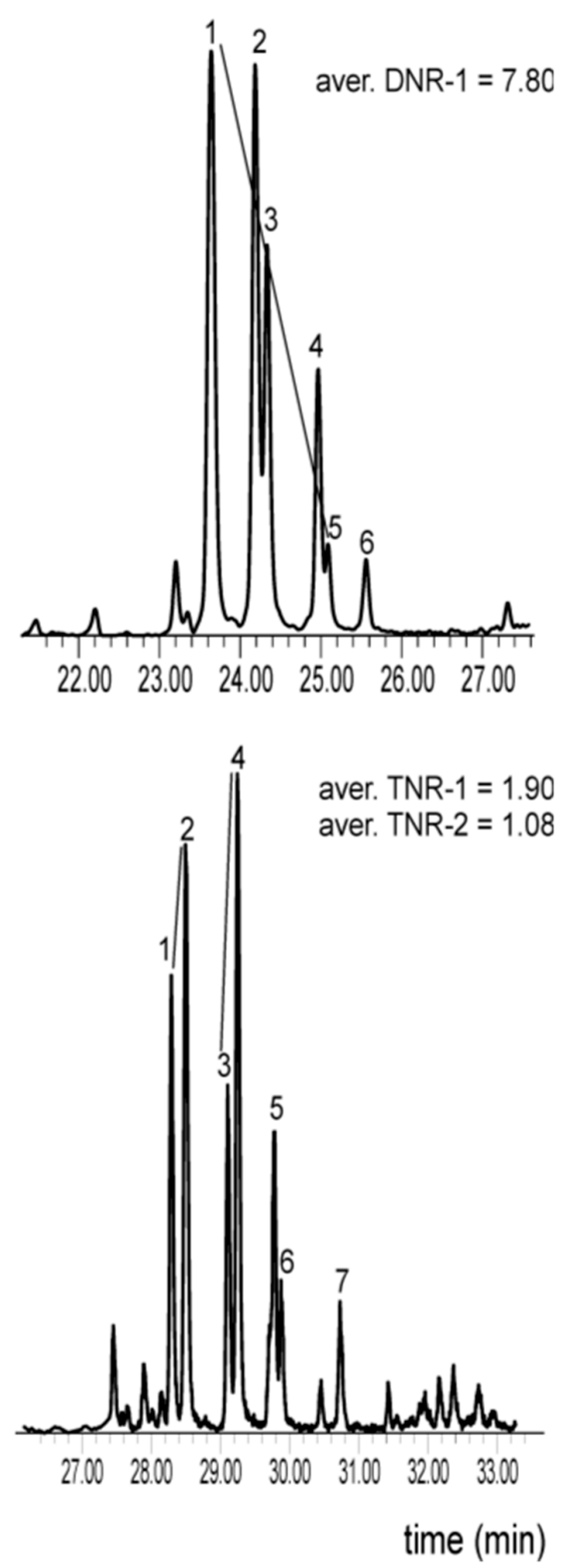

Figure 15. Distribution of alkyl naphthalenes. (a) Dimethylnaphthalenes (DMN), peaks identification: 1: 2,6- + 2,7-DMN, 2: 1,3- + 1,7-DMN, 3: 1,6-DMN, 4: 1,4- + 2,3-DMN, 5: 1,5-DMN, and 6: 1,2-DMN. (b) Trimethylnaphthalenes (TMN), peaks identification: 1: 1,3,6-TMN, 2: 1,3,7-TMN, 3: 1,4,6- + 1,3,5-TMN, 4: 2,3,6-TMN, 5: 1,2,7-+ 1,6,7-TMN, 6: 1,2,6-TMN, and 7: 1,2,5-TMN. 
a

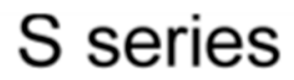

aver. $\mathrm{MPI}-3=1.22$

aver MPI-1 $=0.57$
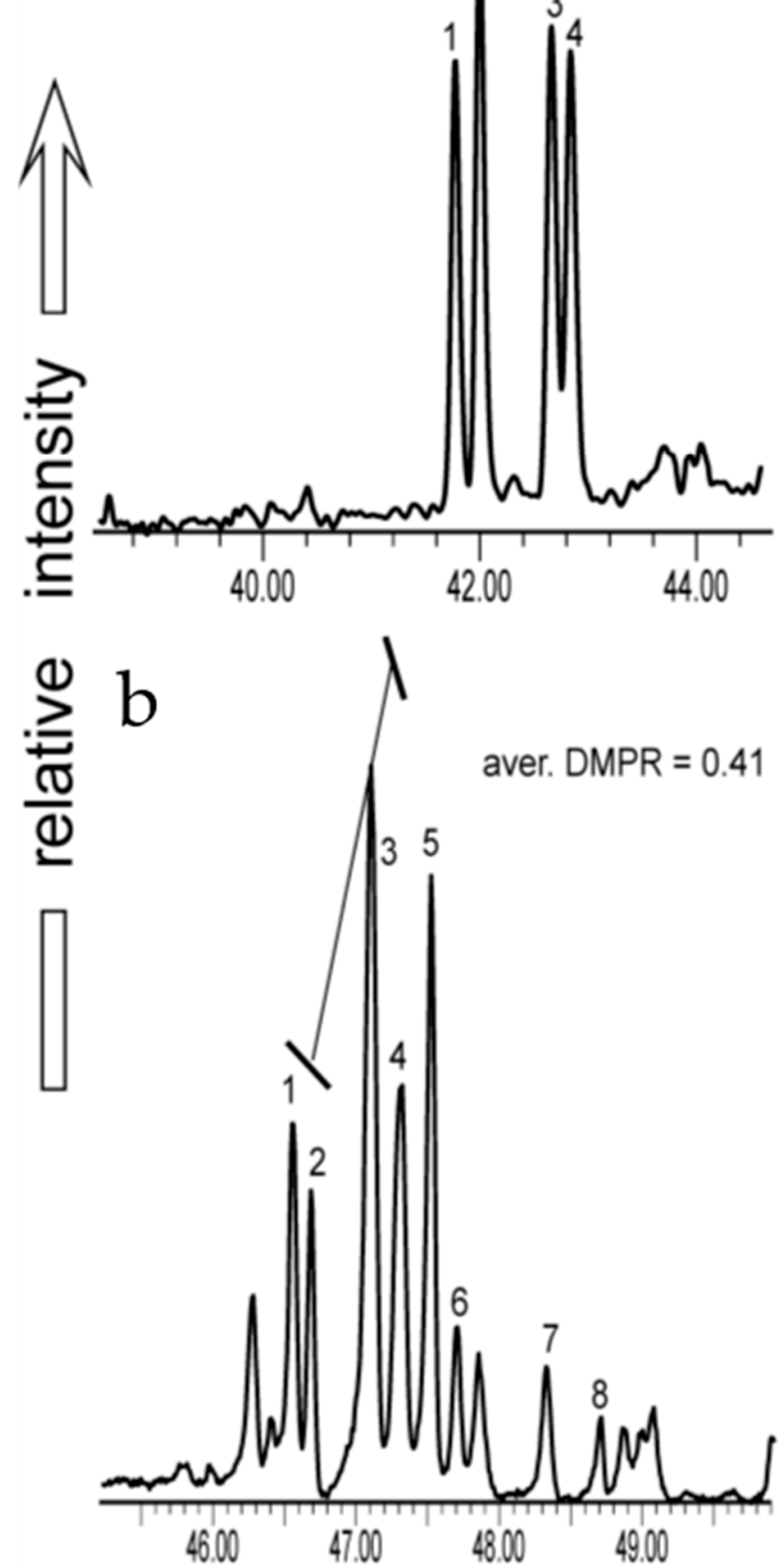

$\mathrm{N}$ series
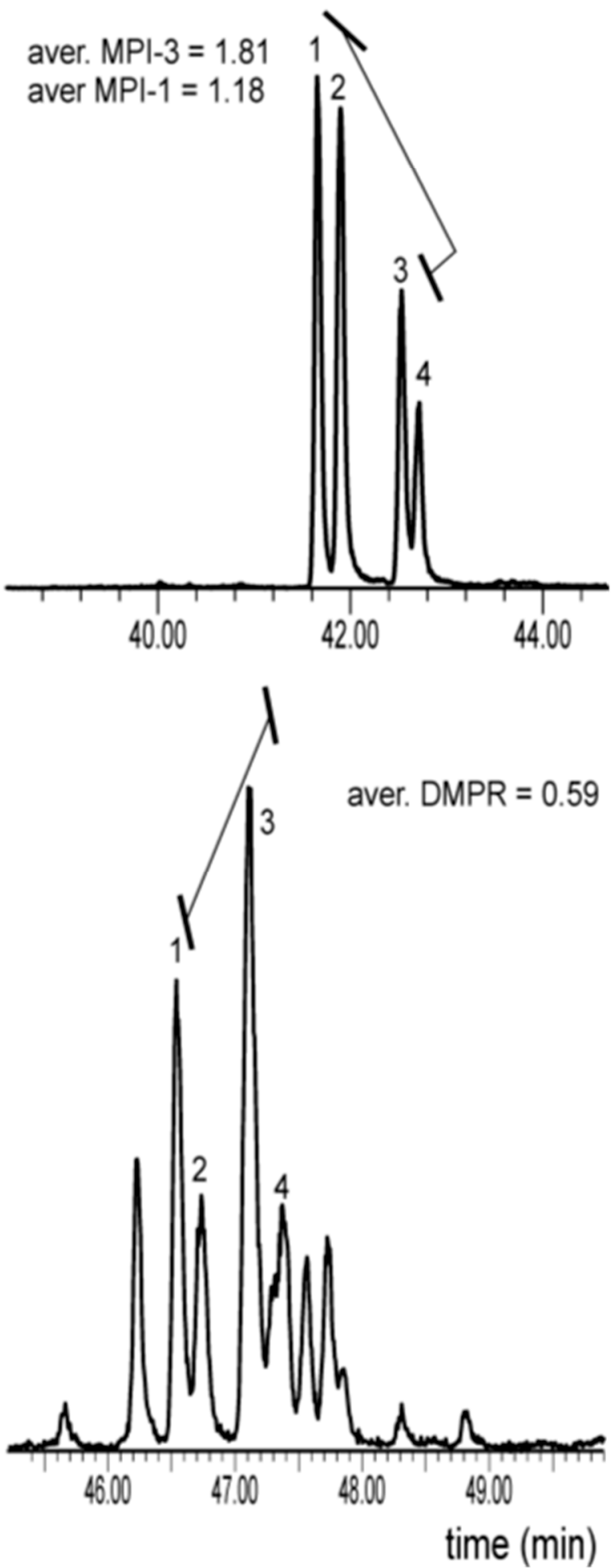

Figure 16. Distribution of alkyl phenanthrenes. (a) Methylphenanthrenes (MP), peaks identification: 1: 3-MP, 2: 2-MP, 3: 4-MP, and 5, 1-MP. (b) Dimethylphenanthrenes (DMP), peaks identification: 1, 2,6-DMP, 2, 2,7-DMP, 3, 3,10 + 1,3 + 2,10 + 3,9-DMP, 4: 1,6 + 2,9-DMP, 5: 1,7-DMP, 6: 2,3-DMP, 7: 1,9 + 4,9-DMP, and 8: 1,8-DMP. 


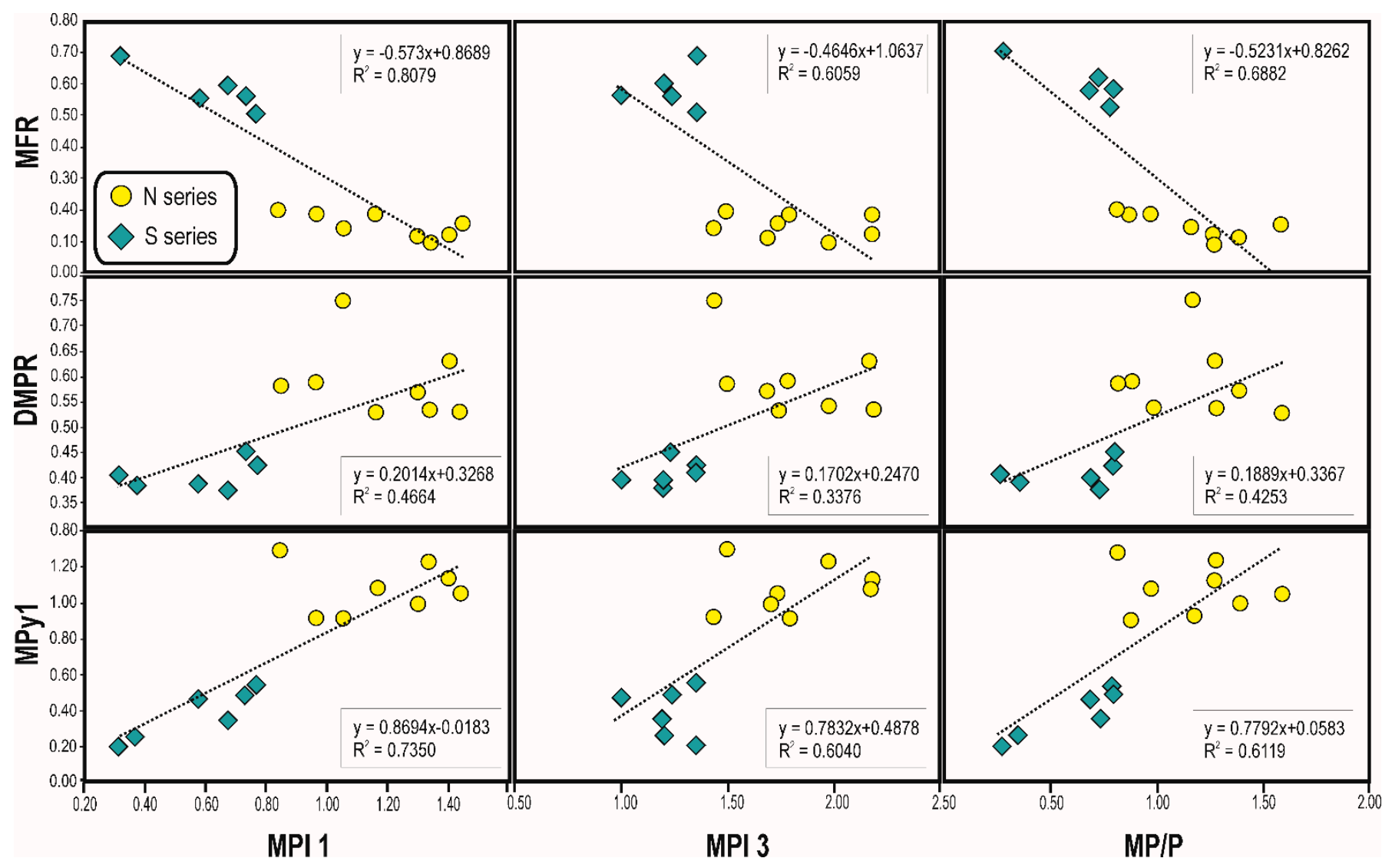

Figure 17. Correlations of PAHs diagnostic ratios.

\section{Conclusions}

The organic geochemistry indicates that the primary organic material of the rocks was deposited under dysoxic conditions, most probably in an estuarine and/or shelf environment. It is a mixture of kerogen II and III with a variable input of terrestrial material. The maturity of the organic matter prior to the thermal event that altered its features was ended diagenesis/early catagenesis, at least.

After normal maturation within a coal-bearing deposit, the organic matter was subjected to heating and weathering, causing coal seams to disappear. Changes recorded by organic petrology (lack of liptinite), mineralogy (hematite, anatase, hydroxylapatite formation), palynology (coloration) and chemical composition (enrichment in elements associated with new-mineral formation) and, most significantly, organic-geochemical data, all serve to identify an intra-deposit paleofire as the most likely reason for the disappearance. The intra-deposit fire, which began at an outcrop of the neighboring coal seam, migrated down the seam. Rocks in close contact with the burning seam, burned out at a high temperature, essentially losing their organic matter totally (S1-S6 reddish rocks). When most of the oxygen had been exhausted, the remaining coal seam began to smolder, creating a hot zone that probably survived for a long time underground. This affected surrounding rocks located further away and deeper (N1-N8 dark grey rock). Long heating at relatively low temperatures without access to oxygen increased values of geochemical ratios and caused formation of heavier PAHs. Compounds expelled from rocks so heated migrated to others, including rocks earlier burned out, thus the apparent discrepancy between the presence of residual pyrolytical $n$-alkanes that had migrated into these rocks and the low values of geochemical ratios based on aromatic hydrocarbons due to short-term heating.

Paleotemperature due to the coal seam fire, registered by samples collected from both northern and southern parts of the Jas-Mos mining area, a part of the Jastrzebie-Bzie Coal Mine, can be estimated as having been $100-150{ }^{\circ} \mathrm{C}$, based on palynology and limited 
changes in chemical-, organic- and mineral-matter composition. Peat combustion in the Early Pennsylvanian times could have occurred locally, but the methodology used did not deliver any evidence for such. If peat fires occurred, any evidence was later obscured/reset by coal-seam burning and weathering.

Author Contributions: Conceptualization, J.C., M.J.F. and D.J.; methodology, M.J.F., J.C., M.M.-K., P.F.; software, J.C., M.J.F., M.M.-K., D.J. and P.F.; validation, J.C. and M.J.F.; formal analysis, M.J.F., P.F., M.M.-K. and J.C.; investigation, D.J. and J.C.; resources, D.J. and A.M.; data curation, J.C.; writing—original draft preparation, M.J.F., J.C., M.M.-K., P.F. and D.J.; writing—review and editing, J.C. and M.J.F.; visualization, J.C., M.J.F., M.M.-K., D.J. and P.F.; supervision, J.C. and M.J.F.; project administration, J.C.; funding acquisition, J.C., D.J. and M.J.F. All authors have read and agreed to the published version of the manuscript.

Funding: This research was funded by the National Science Centre, Poland, grant No 2016/21/B/ ST10/02293.

Acknowledgments: Tomasz Krzykawski and Kamila Banasik are thanked for conducting XRD and Raman spectroscopy. We are grateful to Janusz Rduch and the whole geologists' team of the JAS-MOS coal mine for sample collections. Pádhraig Kennan (University College Dublin, Ireland) is thanked for language correction.

Conflicts of Interest: The authors declare no conflict of interest.

\section{References}

1. Kowalski, W.C. Procesy wietrzeniowe i epigenetyczne w obrębie pstrych utworów Rybnickiego Okregu Węglowego. Prz. Geol. 1983, 31, 591-595. (In Polish and English Summary).

2. Gabzdyl, W.; Probierz, K. The occurrence of anthracites in the area characterised by low rank coals in the Upper Silesian Coal Basin of Poland. Int. J. Coal Geol. 1987, 7, 209-225. [CrossRef]

3. Klika, Z.; Osovsky, M. Thermally altered coal from Upper Silesian Coal Basin. J. Czech Geol. Soc. 1999, 44, 343-352.

4. Probierz, K. Coal Petrology in recognition of coking coal in Jastrzębie area. Kwart. Górnictwo Geol. 2012, 7, 87-117. (In Polish and English Summary).

5. Klika, Z. Geochemistry of Coal from Region of the Red Beds Bodies of the Upper Silesian Coal Basin; VSB-Technical University Ostrava, HGF-Faculty of Minig and Geology: Ostrava, Czech Republic, 1998; pp. 1-85.

6. Klika, Z.; Koszubek, T.; Martinec, P.; Kliková, C.; Dostál, Z. Mathematical modeling of bituminous coal seams burning contemporaneously with the formation of a variegated beds body. Int. J. Coal Geol. 2004, 59, 137-151. [CrossRef]

7. Muszyński, M.; Skowroński, A.; Lipiarski, I. Red beds of the collapse-type breccia from the "Marcel” Coal Mine (Upper Silesian Coal Basin). Geologia 2006, 32, 345-367, (In Polish and English Summary).

8. Jura, D. Discordances of the top surface of Carboniferous deposits of the Upper Silesian Coal Basin. Pol. Geol. Inst. Spec. Pap. 2002, 7, 125-132.

9. Jureczka, J.; Dopita, M.; Gałka, M.; Krieger, W.; Kwarciński, J.; Martinec, P. Geological Atlas of Coal Deposits of the Polish Czech Patrs of the Upper Silesian Coal Basin 1:200 000; Polish Geological Institute: Warszawa, Poland, 2005.

10. Jurczak-Drabek, A. Petrographical Atlas of the Deposits Upper Silesian Coal Basin 1:300 000; Polish Geological Institute: Warszawa, Poland, 1996.

11. Wagner, M. Petrological Character of Bituminous Coal from the Mottled Sediments (Upper Carboniferous), Southern Part of Rybnik Coal District. Geologia 1983, 9, 87-105. (In Polish and English Summary).

12. Kotas, A. Geological bacground. In Coal-Bed Methane Potential of the Upper Silesian Coal Basin; Państwowy Instytut Geologiczny: Warszawa, Poland, 1994; Volume 142, pp. 6-15.

13. Jura, D. Late Variscan and Alpine Geodynamics of the Upper Silesian Coal Basin. In Proceedings of the XIII Congress of the Carboniferous and Permian; Polish Geological Institute: Warsaw, Poland, 1997; Volume 157, pp. 169-176.

14. Jura, D. Morphotectonics and evolution of discordances of different age oresent in the top surface of the Carboniferous of the Upper Silesian Coal Basin. Pr. Nauk. Uniw. Slaskiego Katowicach 1952, 2001, 1-176. (In Polish and English summary).

15. Kędzior, S. Distribution of methane contents and coal rank in the profiles of deep boreholes in the Upper Silesian Coal Basin, Poland. Int. J. Coal Geol. 2019, 202, 190-208. [CrossRef]

16. Kotarba, M.J.; Clayton, J.L. A stable carbon isotope and biological marker study of Polish bituminous coals and carbonaceous shales. Int. J. Coal Geol. 2003, 55, 73-94. [CrossRef]

17. Dill, H.G.; Sachsenhofer, R.F. Fossil fuels, ore and industrial minerals. In The Geology of Central Europe; The Geological Society: London, UK, 2008; pp. 1341-1449.

18. Jura, D.; Trzepierczyński, J. Morphotectonic development of the sub-Permian surface along the Upper Silesian Coal Basin. In Proceedings of the XIII Congress of the Carboniferous and Permian; Polish Geological Institute: Warsaw, Poland, 1997; Volume 157, pp. 177-182. 
19. Kim, A.G. Coal formation and the origin of coal fires. In Coal and Peat Fires, A Global Perspective; Stracher, G.B., Prakash, A., Sokol, E.V., Eds.; Elsevier: Amsterdam, The Netherlands, 2011; Volume 1, pp. 1-23.

20. Sokol, E.V.; Maksimova, N.V.; Nigmatulina, E.N.; Sharygin, V.V.; Kalugin, V.M. Combustion Metamorphism; SB RAS: Novosibirsk, Russia, 2005; pp. 1-312, (In Russian, with some English Abstracts).

21. Stracher, G.B.; Prakash, A.; Sokol, E.V. Coal and Peat Fires: A Global Perspective; Elsevier: Amsterdam, The Netherlands, 2011; Volume 1, pp. 1-357.

22. Stracher, G.B.; Prakash, A.; Sokol, E.V. Coal and Peat Fires: A Global Perspective; Elsevier: Amsterdam, The Netherlands, 2013; Volume 2, pp. 1-554.

23. Stracher, G.B.; Prakash, A.; Sokol, E.V. Coal and Peat Fires: A Global Perspective; Elsevier: Amsterdam, The Netherlands, 2015; Volume 3, pp. 1-786.

24. Martinec, P.; Dopita, M. Paleorelief of the epivariscan platform and its rocks mantle. In Geology of the Czech Part of the Upper Silesian Basin; Ministry of the Environment of the Czech Republik: Praha, Czech Republic, 1997; pp. 181-187. (In Czech and English Summary).

25. Krs, M.; Kssová, M.; Martinec, P.; Pruner, P. Paleomagnetism of the Carboniferous and Variegated Layers of the Moravian-Silesian Region. Geol. Carpathica 1993, 44, 301-314.

26. Klika, Z.; Kraussova, J. Propierties of altered coals associated with Carboniferous red beds in the Upper Silesian Coal Basin and their tentative classification. Int. J. Coal Geol. 1993, 22, 217-235. [CrossRef]

27. Yoksoulian, L.E.; Rimmer, S.M.; Rowe, H.D. Anatomy of an intruded coal, II: Effect of contact metamorphism on organic $\delta^{13} \mathrm{C}$ and implications for the release of thermogenic methane, Springfield (No. 5) Coal, Illinois Basin. Int. J. Coal Geol. 2016, 158, 129-136. [CrossRef]

28. Rahman, M.W.; Rimmer, S.M.; Rowe, H.D.; Huggett, W.W. Carbon isotope analysis of whole-coal and vitrinite from intruded coals from the Illinois Basin: No isotopic evidence for thermogenic methane generation. Chem. Geol. 2017, 453, 1-11. [CrossRef]

29. Rahman, M.W.; Rimmer, S.M.; Rowe, H.D. The impact of rapid heating by intrusion on the geochemistry and petrography of coals and organic-rich shales in the Illinois Basin. Int. J. Coal Geol. 2018, 187, 45-53. [CrossRef]

30. Sanders, M.M.; Rimmer, S.M. Revisiting the thermally metamorphosed coals of the Transantarctic Mountains, Antarctica. Int. J. Coal Geol. 2020, 228, 103550. [CrossRef]

31. Ciesielczuk, J.; Górka, M.; Fabiańska, M.J.; Misz-Kennan, M.; Jura, D. The influence of heating on the carbon isotope composition, organic geochemistry and petrology of coal from the Upper Silesian Coal Basin (Poland): An experimental and field study. Int. J. Coal Geol. 2021, 241, 103749. [CrossRef]

32. ISO 7404-2. Methods for the Petrographic Analysis of Coals_Part 2: Methods of Preparing Coal Samples; ISO: Geneva, Switzerland, $2009 ; 12 p$.

33. ISO 7404-3. Methods for the Petrographic Analysis of Coals_Part 3: Method of Determining Maceral Group Composition; ISO: Geneva, Switzerland, 2009; $7 \mathrm{p}$.

34. International Committee for Coal and Organic Petrology. New vitrinite classification (ICCP system 1994). Fuel 1998, 77, 349-358. [CrossRef]

35. International Committee for Coal and Organic Petrology. New inertinite classification (ICCP system 1994). Fuel 2001, 80, 459-471. [CrossRef]

36. Pickel, W.; Kus, J.; Flores, D.; Kalaitzidis, S.; Christanis, K.; Cardott, B.J.; Misz-Kennan, M.; Rodrigues, S.; Hentschel, A.; Hamor-Vido, M.; et al. ICCP. Classification of liptinite-ICCP System 1994. Int. J. Coal Geol. 2017, 169, 40-61. [CrossRef]

37. ISO 7404-5. Methods for the Petrographic Analysis of Coals_Part 5: Method of Determining Microscopically the Reflectance of Vitrinite; ISO: Geneva, Switzerland, 2009; 14p.

38. Wood, G.; Gabriel, A.M.; Lawson, J.C. Palynological techniques-Processing and microscopy. In Palynology: Principles and Applications; Jansonius, J., McGregor, D.C., Eds.; American Association of Stratigraphic Palynologists Foundation: Salt Lake City, UT, USA, 1996; Volume 1, pp. 29-50.

39. Philp, R.P. Fossil Fuel Biomarkers. Application and Spectra; Elsevier: Amsterdam, The Netherlands, 1985.

40. Wiley/NBS. Registry of Mass Spectral; John Wiley \& Sons, Inc.: Hoboken, NJ, USA, 2012.

41. Jureczka, J.; Kotas, A. Coal deposits. Upper Silesian Coal Basin. In The Carboniferous System in Poland; Zdanowski, A., Żakowa, H., Eds.; Polish Geological Institute: Warsaw, Poland, 1995; pp. 164-173.

42. Parzentny, H.R. Spatial macroscale variability of the role of mineral matter in concentrating some trace elements in bituminous coal in a coal basin-A case study from the Upper Silesian Coal Basin in Poland. Minerals 2020, 10, 422. [CrossRef]

43. Ward, C.R. Analysis, origin and significance of mineral matter in coal: An updated review. Int. J. Coal Geol. 2016, 165, 1-27. [CrossRef]

44. Křibek, B.; Sýkorová, I.; Veselovský, F.; Laufek, F.; Malec, J.; Knésl, I.; Majer, V. Trace element geochemistry of self-burning and weathering of a mineralized coal waste dump: The Novátor mine, Czech Republic. Int. J. Coal Geol. 2017, 173, 158-175. [CrossRef]

45. Finkelman, R.B.; Dai, S.; French, D. The importance of minerals in coal as the hosts of chemical elements. Int. J. Coal Geol. 2019, 212, 103251. [CrossRef]

46. Seredin, V.V.; Dai, S. Coal deposits as potential alternative sources for lanthanides and yttrium. Int. J. Coal Geol. 2012, 94, 67-93. [CrossRef]

47. Ward, C.R. Analysis and significance of mineral matter in coal seams. Int. J. Coal Geol. 2002, 50, 135-168. [CrossRef] 
48. Clayton, G.; Coquel, R.; Doubinger, J.; Gueinn, K.; Loboziak, S.; Owens, B.; Streel, M. Carboniferous Spores of Western Europe. Illustration and Zonation. Report of Commission Internationale de Microflore du Paléozoïque, Working Group on Carboniferous Stratigraphical Palynology. Meded. Rijks Geol. Dienst 1977, 29, 1-71.

49. Batten, J. Palynofacies, palaeoenvironments and petrolum. J. Micropaleont. 1982, 1, 107-114. [CrossRef]

50. Batten, D.J. Palynofacies and palaeoenvironmental interpretation. In Palynology: Principles and Applications; Jansonius, J., McGregor, D.C., Eds.; American Association of Stratigraphy Palynologists Foundation: Salt Lake City, UT, USA, 1996; Volume 3, pp. 1011-1064.

51. Traverse, A. Paleopalynology, 2nd ed.; Springer: Dordrecht, The Netherlands, 2008; pp. 1-813.

52. Fabiańska, M.J.; Ćmiel, S.R.; Misz-Kennan, M. Biomarkers and aromatic hydrocarbons in bituminous coals of Upper Silesian Coal Basin: Example from 405 coal seam of the Zaleskie Beds (Poland). Int. J. Coal Geol. 2013, 107, 96-111. [CrossRef]

53. Misz-Kennan, M.; Fabiańska, M.J. Thermal transformation of organic matter in coal waste from Rymer Cones (Upper Silesian Coal Basin, Poland). Int. J. Coal Geol. 2010, 81, 343-358. [CrossRef]

54. Misz-Kennan, M.; Fabiańska, M.J. Application of organic petrology and geochemistry to coal waste studies. Int. J. Coal Geol. 2011, 88, 1-23. [CrossRef]

55. Misz-Kennan, M. Thermal alterations of organic matter in coal wastes from Upper Silesia, Poland. Mineralogia 2010, 41, 105-236. [CrossRef]

56. Nádudvari, Á.; Fabiańska, M.J. Use of geochemical analysis and vitrinite reflectance to assess different self-heating processes in coal-waste dumps (Upper Silesia, Poland). Fuel 2016, 181, 102-119. [CrossRef]

57. Peters, K.E.; Walters, C.C.; Moldowan, J.M. The Biomarker Guide. Biomarkers and Isotopes in Petroleum Exploration and Earth History; Cambridge University Press: Cambridge, UK, 2005.

58. Tissot, B.P.; Welte, D.H. Petroleum Formation and Occurrence, 2nd ed.; Springer: Berlin/Heidelberg, Germany, 1984.

59. Bray, E.E.; Evans, E.D. Distribution of n-paraffins as a clue to recognition of source beds. Geochim. Cosmochim. Acta 1961, 22, 2-15. [CrossRef]

60. Didyk, B.M.; Simoneit, B.R.T.; Brassell, S.C.; Eglington, G. Organic geochemical indicators of palaeoenvironmental conditions of sedimentation. Nature 1978, 272, 216-222. [CrossRef]

61. Leythaeuser, D.; Schwarzkopf, T. The pristane/n-heptadecane ratio as an indicator for recognition of hydrocarbon migration effects. Org. Geochem. 1986, 10, 191-197. [CrossRef]

62. Seifert, W.K.; Moldowan, J.M. Use of biological markers in petroleum exploration. Methods Geochem. Geophys. 1986, 24, 261-290.

63. Huang, W.-Y.; Meinschein, W.G. Sterols as ecological indicators. Geochim. Cosmochim. Acta 1979, 43, 739-745. [CrossRef]

64. Fabiańska, M.J.; Smołka-Danielowska, D. Biomarker compounds in ash from coal combustion in domestic furnaces (Upper Silesia Coal Basin, Poland). Fuel 2012, 102, 333-344. [CrossRef]

65. Fabiańska, M.; Kozielska, B.; Konieczyński, J. Differences in the Occurrence of Polycyclic Aromatic Hydrocarbons and Geochemical Markers in the Dust Emitted from Various Coal-Fired Boilers. Energy Fuels 2017, 31, 2585-2595. [CrossRef]

66. Schubert, P.; Schantz, M.; Sander, L.; Wise, S. Determination of polycyclic aromatic hydrocarbons with molecular weight 300 and 302 in environmental-matrix standard reference materials by gas chromatography/ mass spectrometry. Anal. Chem. 2003, 75, 234-246. [CrossRef]

67. Masala, S.; Bergvall, C.; Westerholm, R. Determination of benzo[a]pyrene and dibenzopyrenes in a Chinese coal fly ash certified reference material. Sci. Total Environ. 2012, 432, 97-102. [CrossRef] [PubMed]

68. Seidel, A.; Frank, H.; Behnke, A.; Schneider, D.; Jacob, J. Determination of dibenzo[a,l]pyrene and other fjord-region PAH isomers with mw 302 in environmental samples. Polycycl. Aromat. Compd. 2004, 24, 759-771. [CrossRef]

69. Pace, C.; Betowski, L. Measurement of high-molecular-weight polycyclic aromatic hydrocarbons in soils by particle beam high performance liquid chromatography-mass spectrometry. J. Am. Soc. Mass Spectrom. 1995, 6, 597-607. [CrossRef]

70. Prus, W.; Fabiańska, M.J.; Łabno, R. Geochemical markers of soil anthropogenic contaminants in polar scientific stations nearby (Antarctica, King George Island). Sci. Total. Environ. 2015, 518-519, 266-279. [CrossRef] [PubMed]

71. Sauvain, J.; VuDuc, T. Approaches to identifying and quantifying polycyclic aromatic hydrocarbons of molecular weight 302 in diesel particulates. J. Sep. Sci. 2004, 27, 78-88. [CrossRef] [PubMed]

72. Bergvall, C.; Westerholm, R. Identification and determination of highly carcinogenic dibenzopyrene isomers in air particulate samples from a street canyon, a rooftop, and a subway station in Stockholm. Environ. Sci. Technol. 2007, 41, 731-737. [CrossRef]

73. Mininni, G.; Sbrilli, A.; Guerriero, E.; Rotatori, M. Polycyclic aromatic hydrocarbons formation in sludge incineration by fluidised bed and rotary kiln furnace. Water Air Soil Pollut. 2004, 154, 3-18. [CrossRef]

74. Ikegami, M. Soot formation Fundamentals. In Growth and Destruction of Soot Particles; Someya, T., Ed.; Springer: Berlin/Heidelberg, Germany, 1993; pp. 161-204.

75. Sarofim, A.F.; Longwell, J.P.; Wornat, M.J.; Mukherjee, J. The Role of Biaryl Reactions in PAH and Soot Formation. In Soot Formation in Combustion; Bockhorn, H., Ed.; Springer: Berlin/Heidelberg, Germany, 1994; pp. 485-499.

76. Ravindra, K.; Sokhi, R.; Van Grieken, R. Atmospheric polycyclic aromatic hydrocarbons: Source attribution, emission factors and regulation. Atmos. Environ. 2008, 42, 2895-2921. [CrossRef]

77. Radke, M.; Welte, D.H. The methylphenanthrene index (MPI): A maturity parameter based on aromatic hydrocarbons. Adv. Org. Geochem. 1981, 1983, 504-512.

78. Radke, M. Organic geochemistry of aromatic hydrocarbons. Adv. Pet. Geochem. 1988, 2, 141-203. 
79. Radke, M.; Vriend, S.P.; Ramanampisoa, L.R. Alkyldibenzofurans in terrestrial rocks: Influence of organic facies and maturation. Geochim. Cosmochim. Acta 2000, 64, 275-286. [CrossRef]

80. Alexander, R.; Kagi, R.I.; Rowland, S.J.; Sheppard, P.N.; Chirila, T.V. The effects of thermal maturation on distributions of dimethylnaphthalenes and trimethylnaphthalenes in some ancient sediments and petroleums. Geochim. Cosmochim. Acta 1985, 49, 385-395. [CrossRef]

81. Kruge, M.A. Determination of thermal maturity and organic matter type by principal components analysis of the distributions of polycyclic aromatic compounds. Int. J. Coal Geol. 2000, 43, 27-51. [CrossRef]

82. Ishiwatari, R.; Fukushima, K. Generation of unsaturated and aromatic hydrocarbons by thermal alteration of young kerogen. Geochim. Cosmochim. Acta 1979, 43, 1343-1349. [CrossRef]

83. Garrigues, P.; Connan, J.; Parlanti, E.; Bellocq, J.; Ewald, M. Relationship between rank and distribution of methylaromatic hydrocarbons for condensates of different origins. Org. Geochem. 1988, 13, 1115-1121. [CrossRef] 